Article

\title{
The Human Right to Water in Law and Implementation
}

\author{
Norbert Brunner ${ }^{1, *}$, Vijay Mishra ${ }^{1}$, Ponnusamy Sakthivel ${ }^{2}$, Markus Starkl ${ }^{3}$ and \\ Christof Tschohl ${ }^{4}$
}

1 CEMDS (Centre for Environmental Management and Decision Support), Gregor Mendel Str. 33, 1180 Vienna, Austria; E-Mails: office@cmds.org or vijaym263@gmail.com

2 School of Excellence in Law, The Tamil Nadu Dr. Ambedkar Law University, 600028 Chennai, India; E-Mails: sakthivel@tndalu.ac.in orProf.Sakthivel@gmail.com

3 Competence Centre for Decision-Aid in Environmental Management, DIBB, University of Natural Resources and Life Science (BOKU), 1180 Vienna, Austria; E-Mail: Markus.Stark1@BOKU.ac.at

4 Centre of Digital Human Rights at the Research Institute (RI), 1170 Vienna, Austria;

E-Mail: Christof.Tschohl@researchinstitute.at

* Author to whom correspondence should be addressed; E-Mail: Norbert.Brunner@BOKU.ac.at Tel.: +43-1-47654-5055; Fax: +43-1-47654-5092.

Academic Editor: Frank Pasquale

Received: 19 June 2015 / Accepted: 30 July 2015 / Published: 7 August 2015

\begin{abstract}
Recent concerns about alleged insufficient water provision to the poor in Detroit, USA, has put the Human Right to Water (HRW) into the international discussion. The paper asks: "To what extent did international human rights treaties make HRW judiciable?" and "How did government policies implement it?" In a cross-country comparison of performance indicators, merely accepting HRW has not been helpful in promoting affordable access to potable water or sanitation facilities close to the home, amongst the reasons being deficiencies in water-governance. Case-law confirmed that with respect to affordable access HRW obliges governments to a "progressive realization" only, also in countries accepting HRW (India, South Africa). The paper focuses on the resulting positive state obligation to establish funding programs for better water and sanitation services and analyzes funding policies by a mathematical model of policy goals. It identifies two viable goals namely the successful support for the poor, as in developing countries, and the most economic use of public funds, as in industrialized countries. Other goals conceivable for the model have been tried in the past and failed.
\end{abstract}


Keywords: access to improved water and sanitation services; cross country comparison; governance indicators; goals for infrastructure funding; mathematical policy modeling; progressive realization of social and economic human rights

\section{Introduction}

Globally, access to water and sanitation are at alarmingly low levels [1]. In 2012 about 700 million people lived in communities without access to any source of safe drinking water and a billion people practiced open defecation, as they had no access to sanitation facilities [2]. Many more people lack household-level access to safe water and hygienic toilets (half of the world population in 2010 [3], a third in 2015 [4]). Not included in this count are vulnerable groups in rich countries. In the USA people facing "conditions similar to those in developing countries" may be found among the homeless and tenants of mobile homes [5].

This is clearly a social and a public health problem [6]. People without access to safe water and sanitation facilities close to their homes are vulnerable to waterborne diseases, such as typhoid fever $(6 \%$ infection rate in slums of Kolkata, India [7]), cholera (105,000 infected people during the 2001 outbreak in South Africa [8]), etc. In irregular settlements, problems are aggravated by lacking solid waste disposal and insufficient storm water management; this creates breeding grounds for vectors of malaria and dengue fever. In Sub-Saharan Africa water-fetching is widespread [9]; at least 20\% of households in Burundi, Malawi and Mauretania need an hour or more to walk to the next standpipe and back. Even if water sources are safe, health benefits diminish with such distances [10], and it reduces the capabilities of women and girls since they spend time for water-fetching rather than for education [11] or income-generation [12].

Globally, even where homes are connected to sewers, the disposal of human excreta is often unsafe; e.g., polluted river water used for irrigation caused health risks for farmers and consumers of food crops [13-15]. In 2012 sewage of 1.5 billion people was discharged untreated into rivers [16]. Also in Europe sanitation remained a challenge, with about 30\% of households in Eastern and Southeastern Europe were not connected to sewer in 2009 [17]. Industry responded with off-the-grid systems, but affordable solutions are not yet technically mature [18].

To emphasize the urgency of this problem, in 2010 legally non-binding UNO-resolutions [19,20] declared a Human Right (HR) to water and sanitation. Fifty-two HRW-countries (Section 5) with together $4 \frac{1}{2}$ billion people in their self-perception accept key aspects of the Human Right to Water (HRW) in national law or policies (Figure 1). HRW envisages access to water close to the home and the workplace for everyone and it is the responsibility of governments to ensure water provision [21,22]: Water services should be free of discrimination and affordable for all. Water safe for health should be provided continuously in sufficient amounts for personal and domestic uses (the paper discusses also sanitation, as water and sanitation is closely linked; for a different view: [23]). Relevant thresholds of water provision are 5 LPCD (Liters Per Capita and Day) for survival, plus 20 LPCD for maintaining health (drinking, hygiene), plus 25 LPCD for bathing and food preparation in the household; 100 LPCD are sufficient for the most urgent domestic water needs [24,25]. The minimum requirement for economic development should be around 135 LPCD [26]. 


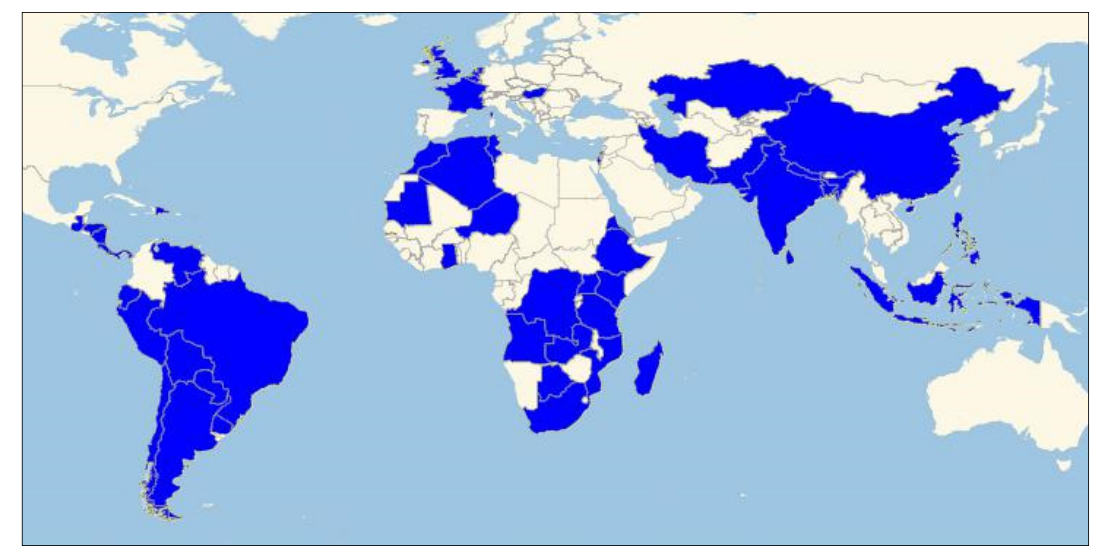

Figure 1. World map of 52 countries that accept the human right to water and sanitation in laws or policies; Notes: Graphics with Mathematica 10 of Wolfram Research, based on Section 5.2.

This paper explores HRW and affordability: Affordability of water services is an emerging problem for developing countries and also for rich countries. Ageing metropolitan infrastructure needs costly maintenance-works and improvements [27,28], whereby cost recovery may make water and sewer connections unaffordable for the urban poor. The situation of Detroit, Michigan, USA, is exemplary for a largely unresolved issue [29]: How to protect the interests of the residents of insolvent cities? Although the City Charta declares to respect HRW, since June 2014 the Water and Sewerage Department of Detroit disconnected water services from more than 30,000 households that did not pay their bills (some very high due to leakages). Disconnections were challenged at court and UNO-experts expressed their concern that the poor may be genuinely unable to pay [30,31].

\section{Goal of the Paper}

Under various HR-treaties, the acceding states have an obligation for a "progressive realization" of HRW (Article 2 CESCR; see the Appendix for a list of abbreviations), in particular to provide affordable access to water at (or close to the) home. Some authors cautioned that while HRW may be a worthwhile aspiration, rather than caring for affordability of water, policies should focus on poverty alleviation [32]. HRW would be used mainly in anti-privatization rhetoric [33], be insufficient, and result at best in better information [34]. The vague Article 2 CESCR language would not define any obligation [35], leaving HRW as a "second-class, nonjusticiable" right [36]. Other authors maintained that the legal acceptance of HRW would matter [37]. In particular, affordability of water for domestic uses would be amongst the immediately enforceable "minimum core" of HRW [38]. Such analysis was based on studies of few countries (e.g., India and South Africa [34,37]). Further, in various aspects these studies contradicted each other; e.g., in the assessment, if domestic law of a country respected HRW (India) or if the implementation of HRW has been effective (South Africa).

This paper reconsiders this issue under a global perspective and investigates the implementation experiences in terms of international case-law, meaning declaratory views of treaty-bodies for UNO and regional treaties, and domestic case-law, meaning binding court rulings of selected countries. It explores, which aspects of HRW were judiciable. As structural and institutional issues are crucial in addressing HRW [39], the paper compares the success of different policies in implementing HRW by means of 
indicators for the assessment of governance [40,41]. Finally, a linear programming model classifies policy-goals to ensure affordability through funding and elaborates on their exact meaning.

\section{Data and Methods}

All data were taken from published sources (except two user surveys by the authors, where data will be published elsewhere). Therefore, these data are not reproduced here; rather Table A1 of the Appendix exemplifies the information used for the datasets 1 and 2.

Dataset 1 informs about 30 indicators for good governance and HR-fulfillment in 176 countries from three sources (removing countries with incomplete information), and about renewable water resources, water stress, and quantity of water provision in 165 countries from two sources.

- Data [42] inform about HR-fulfillment under twelve aspects (free elections, political prisoners, independence of the judiciary, workers' rights, women's economic rights, right to life, prohibition of torture, freedom of: assembly, speech, religion, movement within the country, and movement abroad). Data summarize reports by Amnesty-International and the USA State Department about the HR-situation in 195 UNO member and observer countries. Annual country assessments were rescaled linearly between 0-no reported violations and 1-reported systematic/widespread HR-violations. For each index the five-year average over 2006 to 2010 was used (reduction of random noise).

- Data [43] by World Bank inform about six governance indicators (voice and accountability, political stability and absence of violence or terrorism, effectiveness of government, regulatory quality, rule of law, and control of corruption) for 215 countries and territories, based on expert interviews. $[44,45]$ discuss the methodology. For each indicator the five-year average over 2006 to 2010 was rescaled linearly between 0 - good governance (indicator value 2.5 ) and 1 -poor governance (indicator value - 2.5 or lower; estimates below this intended minimum were cut off).

- Data [46] with 12 state-fragility indicators of 2013 inform about the social (demographic pressures, vengeance-seeking group grievance from internal tensions, refugees and internal displacement, emigration and brain drain), economic (uneven development, poverty), and political situation (tensions within the elites, legitimacy and corruption, public service provision, respect for HR, faulty security apparatus, external interventions).

- A list by FAO [47] informs about renewable water resources in 199 territories. (Data from 2009 were taken, which fit better to the time span for most governance data.) Data were rescaled to r-LPCD (total available renewable water resources in liters per person per day, based on 2009 population), RWH-potential (Rain Water Harvesting potential; rainfall in liters per $100 \mathrm{~m}^{2}$ per day), and the Millennium Development Goal indicator water stress (proportion of total actually available freshwater resources withdrawn). Climate change may increase water stress in the future [48].

- A list [24] of 81 countries plus Somalia (not in dataset 1) informs where average domestic water provision in 2000 was below 100 LPCD; other countries provided more. Such relatively old data were used to check, if water scarcity in the past may have affected acceptance of HRW.

- Background geo-information was retrieved from Wikipedia [49] (list of countries with a common border, whereby the authors added common channel-like sea-borders to the list). 
Dataset 2 informs about 63 countries. It combines lists [9,50] with 42 and 34 countries informing about lacking access to "improved water sources" (by definition, they are likely to be protected against contamination); for duplicates the larger percentage of deficiencies were used.

It should be cautioned that "improved" is not necessarily safe for human health [51]. Further, water and sanitation infrastructure, which local experts would assess as safe, on closer inspection may be unsafe (e.g., 50\% "hidden failures" for a sample from India: [52]). In addition, [50] informs about lacking access to "improved sanitation" (it separates human excreta from direct contact), to electricity and to "improved cooking methods" (cooking with, e.g., electricity or gas, but not with solid fuels, such as self-collected wood or dried cow-pads). Further, [9] informs about the larger percent of households without piped water. Most of them fetch water (a few get water from the neighbors), and for them [9] informs about the time needed for water fetching and the persons doing it.

With respect to data quality, there were differences between different sources, as data came from different years and were collected by different methods (government sources, surveys). Further, water availability and water use may depend on the region and seasons, as exemplified for the Nigerian Sahel with water use of 12.5 LPCD in the dry season and 40 LPCD in the rainy season [53]. Therefore water fetching and open defecation may be seasonal, allowing no sharp classifications. Further, data do not inform about continuous water availability in sufficient quantities. In developing countries, service interruptions by power failures are common; also in developed countries pressure loss has been identified as a cause for diarrhea outbreaks [54].

Dataset 3 [55] assesses water-governance of 20 countries from the Asia-Pacific region. It informs about six aspects of water legislation, eight aspects of water policies and six aspects of administrative implementation during the decade 2000-2010 based on interviews with experts, using indicators developed in institutional economics [56-58]. Country classifications [56] were rescaled linearly to deficiency indicators; values range between 0-group-4-countries (for most indicators: good governance) and 1-group-1-countries.

The authors conducted a legal analysis based on an international perspective, using as starting point surveys of water-related case-law and HRW-implementation [59,60]. Table A2 of the Appendix summarizes the empirical input of 120+ HRW-related cases (treaty body views and domestic court rulings) from $55+$ countries; in the sequel $\# \mathrm{x}$ refers to case description $\mathrm{x}$ in Table A2. This was complemented by own research to identify HRW-countries and an in-depth analysis at the national level for the prototypical HRW-countries, India and South Africa (cf. [37]). Table A3 of the Appendix (see also Section 5.2) explains why authors classified a country as HRW, pointing out also borderline cases.

The authors conducted household surveys in Madhya Pradesh state, India, with 100+ interviews in slums of Burhanpur and Raisen. As part of a stakeholder analysis (using POSAF [61]), the contingent valuation method was used to assess Willingness To Pay (WTP) of future users for water and sanitation improvements. Respondents stated the amount that they could afford to pay. The problem of upwards bias (an "implausibly high number of persons who say that they are willing to pay the higher prices", as they want change $[62,63]$ ) was avoided by reminding respondents to their ability to pay [64-66]. The method of dichotomous choice was not used; it would require large samples [67,68].

For statistical tests the authors used methods for small sample sizes. All statistical tests were done at the same significance level of $95 \%$, whereby the $95 \%$ confidence intervals were one-sided. Higher 
significance levels were achieved, but not reported, as the purpose was not to suggest causation, but to explore, which problem fields mattered.

As the actual distributions are unknown, parameter-free methods or methods insensitive to distribution assumptions were used [69]: Clopper-Pearson conservative confidence intervals; Fisher exact test for identification of significant contingencies; Mann-Whitney test to identify, whether countries of a certain group had stochastically larger values than others (here "stochastically better/worse" always refers to this test at 95\% significance); T-test for significant correlations. In view of uncertain data, Spearman-rank correlations were used, as they depend on ordinal information only. Confidence intervals for median-WTP were based on Clopper-Pearson confidence intervals. The median was estimated, as the WTP-distribution may not have a mean value [70].

Clopper-Pearson confidence intervals were computed in Microsoft Excel (using the beta distribution). Statistical tests and statistical manipulations (construction of contingency tables, optimal stratification [71]) were done with XL-STAT software, and simulations used XL-Sim software (add-ins to Excel). For Cramér and von Mises distribution-fit-test and maximum likelihood fits Mathematica 10 software was used. Network analysis (simulations) used UCINET 6 software.

The paper did not weigh country performance by population size, as the diversity of government responses mattered. Economic performance (gross domestic product GDP) was not considered, as this aspect is well-researched: Richer countries (higher per capita GDP) tend to have better water-governance [58], they can afford better water infrastructure, and there tends to be more respect for HR, e.g., fewer violations of women's rights [72]. Also Human Development Indicator was not used, as it would duplicate above information.

\section{International and Regional Codification of HRW}

\subsection{UNO-HR-Treaties and Enforcement}

HRW incorporates aspects of "first generation" HR (civil and political rights), "second generation" HR (social, cultural and economic rights) and "third generation" HR (collective rights, such as the right to a healthy environment [73]); further HRW touches all HR-dimensions [74], namely "respect" (protection against unreasonable state interferences), "protect" (positive state-obligations to ensure compliance with HR effectively, in particular on the "horizontal level" of natural and legal persons amongst each other) and "fulfill" (state-obligation to provide an environment, in which all HR can be actually realized). HR-treaties made certain provisions of the Universal Declaration of HR of 1948 legally binding for the acceding states. Literature cautions that this may have had low impact for the everyday practice of governments [75-78]; countries ratifying HR-treaties under the reservation that the "provisions are not self-executing" may not implement them through domestic laws. To make HR-treaties enforceable and guide acceding states in applying them, optional protocols established complaints mechanisms for individuals against states [79]. Countries accepting such mechanisms generally had better HR-records [80]. Further domestic courts might consider HR-treaties and related case-law for the interpretation of ambiguous statutes [81]. Even treaties not applicable to a country may be a source of legal arguments; e.g., ECHR in the USA or India [82,83]. 
Water-related case-law exists for HR-treaties of the first generation. Further, as national legislations respect core CCPR-rights, courts have invoked equivalent domestic rights.

- CAT of 1984 with 156 state parties defines state obligations towards the eradication of torture [84]. This mattered for prison conditions (water and sanitation facilities).

- CERD of 1965 with 175 ratifications guarantees non-discrimination on the basis of race or descent in all aspects. By its General Comment 29 of 2002, access restrictions to water for lower castes or ethnic minorities are discriminatory.

- CCPR of 1966 with 168 parties prohibits discrimination (Article 26), torture (Article 7) and inhumane treatment of prisoners (Article 10); it protects the right to life ( $\$ 1$ Article 6), private homes (Article 17) and rights of minorities (Article 27). Article 10 was interpreted with reference to the Standard Minimum Rules for the Treatment of Prisoners of 1957 (Economic and Social Council Resolution), which foresee ( $\$ 2$ Article 20) that "drinking water shall be available to every prisoner whenever he needs it" [85]. However, CCPR does not mention HRW or the related rights to decent housing or health and its treaty-body denied that e.g., the right to health as such would be protected [86], but certain aspects were within the ambit of CCPR.

Amongst second-generation HR-treaties, HRW is explicitly mentioned in CEDAW, CRC and CRPD and it is relevant for CESCR and CMW. There are no individual complaints procedures under CRC or CMC, and no water-related case-law under CEDAW, CESCR or CRPD: For CEDAW case-law exists since 2004, also about the right to health [87], and for CESCR and CRPD case-law has yet to emerge [88].

- CEDAW of 1979 (187 ratifications) mentions HRW in the context of rural women ( $\$ 2$ Article 14). General Comments 12 of 1999, 26 of 2008, and 27 of 2010 confirmed HRW for rural women and extended it to migrant workers and elderly women.

- CRC of 1989 (194 parties) mentions HRW in the context of the right of children to health and food ( $\$ 2$ Article 24).

- CRPD of 2006 (147 ratifications) mentions HRW in the context of the social protection of disabled persons ( $§ 2$ a Article 28).

- CESCR of 1966 (170 ratifications) protects the right to work (Article 6), to an adequate standard of living (Article 11), and to the highest attainable standard of health (Article 12). General Comment 4 of 1991 explained that decent housing under Article 11 entails "safe drinking water, energy for cooking, heating and lighting, sanitation and washing facilities, means of food storage, refuse disposal, site drainage and emergency services". Also General Comment 12 of 1999 about the right to food mattered for HRW. General Comment 15 of 2002 about HRW developed three key criteria [23]: (a) sufficiency; (b) safety and acceptability (i.e., clean water); and (c) affordability and physical accessibility. $\S 37$ General Comment 15 emphasizes that HRW would define certain "core obligation of immediate effect". However, in the understanding of most governments, HRW is conditional on progressive realization (Section 5). Also $\S 41$ of the Comment cautions that only unwillingness to realize HRW would be a violation, not inability. Further, § 38 emphasizes the obligation for international aid to realize HRW globally. This issue has been discussed in the literature [89-91]. General Comment 18 of 2006 about the right to work emphasized ILO labor-standards [92]. 
- CMW of 1990 (47 parties) addresses working and living conditions of migrant workers and their families (if in a "regular situation": Article 70), which pertains to HRW.

Regardless of accession to Optional Protocols, civil society may inform the treaty-bodies about the HR-situation, when the periodic country reports are evaluated. For instance, with respect to access to water there were issues about migrant workers of African origin under CERD (Italy [93]); about the rural population under CEDAW (Ethiopia [94]) and CESCR (Peru [95]); about indigenous populations under CESCR (Maori in New Zealand [96]); about children in schools under CRC (Kenya [97]); or about disabled persons under CRPD (El Salvador [98]). The CMW treaty-body voiced concerns about the housing situation of migrant families returning to their home-country (Bosnia [99]).

In addition, as happened 2014 with respect to Detroit, USA (Section 1), civil society may contact Special Procedures (experts appointed by the UNO-HR-Council) that investigate under the rules of the Resolution 5/1-Procedure. It addresses "consistent patterns of gross and reliably attested violations of all HR and all fundamental freedoms occurring in any part of the world and under any circumstances" [100]. Input from civil society is also accepted for the Universal Periodic Reviews [101]. It is a cooperative, state-driven process under the auspices of the HR-Council. Governments, rather than HR-experts, assess the HR-performances of UNO-member countries.

In exceptional cases, states complain about each other to a treaty body or turn to the International Court of Justice: Argentina asked Uruguay to take measures against pollution of Uruguay River from the world largest pulp mills authorized by Uruguay. In 2010, the Court found that there is a general obligation under customary international law to conduct a trans-boundary environmental impact assessment [102]; cf. for Europe the ECE Convention on Environmental Impact Assessment in a Trans-boundary Context of 1991.

Further, there are treaties that potentially delimit HRW [103]: ICSID of 1965 (143 ratifications) protects foreign private investors. They may request compensations from governments, if laws and regulations affect their business adversely. For instance, governments terminated contracts with international water companies due to excessive costs of water for the poor. In turn, companies brought these disputes before the International Centre for the Settlement of Investment Disputes (a branch of World Bank). This is the treaty-body under ICSID. However, in a case concerning Argentina (\#2) the treaty-body decided that states are obliged to comply both with their duties out of international investment agreements and with their duties to protect HR. Also, ECtHR found that states need to find a fair balance between property rights and environmental protection (Belgium \#12: protection dominated, Turkey \#100: property rights dominated). Thus, the international discussion today is increasingly emphasizing the necessity of HR-protection-clauses within investment agreements ([104], p. 144).

\subsection{Regional HR-Treaties and Enforcement}

The Organization of American States (35 states with 910 million citizens) has been a forerunner in establishing HRW: ADRDM of 1948 mentions the right to food (Article 11: right to health) and ACHR of 1969 summarily promises progressive realization of the economic, social and cultural rights set forth in the Charter of the Organization of American States. Its Protocol of San Salvador of 1988 guarantees the right to food (Article 12). 
In water-related case-law the rights to life, property, and procedural rights were invoked, e.g., access to a court, equality before law, fair trial. Also the ILO Convention 169 of 1989 mattered (22 ratifications; mostly from Latin America). It protects the rights of indigenous and tribal people; $\S 1$ Article 15 stipulates: "The rights of the peoples concerned to the natural resources pertaining to their lands shall be specially safeguarded".

For the African Union (54 member states with 960 million citizens) the core HR-document is ACHPR (53 ratifications), adopted in 1981. In addition to first generation HR it incorporates the right to health (Article 16) and guarantees non-discrimination in access to public services (Article 13). The right to "free disposal of wealth and natural resources" (Article 21) lets indigenous communities benefit from the resources on their ancestral land (by [105], the "origin of this provision may be traced to colonialism, during which the human and material resources of Africa were largely exploited for the benefit of outside powers"). In a case concerning Kenya (\#63) also religious freedom (Article 8) mattered. In many cultures water bears an important symbolic and religious dimension ([104], p. 103).

Both the Protocol to ACHPR on the Rights of Women in Africa of 2003 (Article 15 about food safety) and the African Charter on the Rights and Welfare of the Child of 1990 (Article 14 on the right to health) mention HRW.

Eleven African countries are (also) members of the League of Arab States (22 member states with 400 million citizens). The Arab Charter on HR of 2004 mentions HRW (Article 39: right to health).

The core HR-document of Council of Europe ( 47 member states with 820 million citizens) is ECHR of 1950. ECHR protects first generation HR only, as the drafters "pursued a short and non-controversial text" [106]. Certain second generation HR have been added by the First Additional Protocol to ECHR, namely the right to property (Article 1 Protocol 1) and the right to education (Article 2 Protocol 1). ECHR does not protect HRW, a right to a decent standard of living or a right to a healthy environment [107]. However, the drafting of an additional protocol to ECHR about environmental rights is discussed [108]. Discrimination with respect to access to water is within the ambit of the general prohibition of discrimination under Protocol 12 of 2000 to ECHR (18 ratifications). For an accessory discrimination in substantive ECHR-rights Article 14 applies. In water-related case-law, the rights to life (Article 2), to private life (Article 8), to free speech (Article 10), to property (Article 1 Protocol 1), the protection against torture (Article 3) and procedural rights (Article 6) have been invoked.

ESC of 1961 (revised 1996) protects second generation HR, e.g., the right to health (Article 11) and to adequate housing (Article 31). Other treaties address environmental protection [109]. Article 19 European Charter on Water Resources (a Committee of Ministers recommendation of 2001) mentions HRW together with the obligation of users to pay for water services.

Further, there are regional UNO-instruments related to HRW, e.g., the ECE Protocol on Water and Health of 1999 to the Convention on the Protection and Use of Trans-boundary Watercourses and International Lakes of 1992. Its Article 5 demands the provision of "equitable access to water". The ECE Convention on Access to Information, Public Participation in Decision-making and Access to Justice in Environmental Matters of 1998 promotes civil society participation for water-body related issues.

With respect to complaints procedures, there exists HRW-related case-law under ACHPR, ACHR, ADRDM, ECHR, and ESC. Treaty-bodies views are declaratory and implemented by different follow-up procedures: For instance, execution of ECtHR-judgments is monitored by the Committee of Ministers of the Council of Europe. Compliance is rather high in Europe [110], as the concerned states accept that 
judgments are binding for them. Thereby views by UNO-treaty-bodies gain weight, as ECtHR reviews them [111].

- In Africa, under ACHPR, individuals may direct communications to ACnHPR, operative since 1988. ACtHPR was established in 1998 and 27 states accept its jurisdiction. It may receive cases submitted by ACnHPR or by states. Five states accept that individuals may complain to ACtHPR; case-law is evolving with 26 cases (on 12 2014) in data base [112].

- In Europe, ECHR permits individual applications to ECtHR [113]. Under ESC, 14 countries accept the jurisdiction of the ECeSR for a collective complaints procedure, accessible for trade unions and certain organizations; individuals cannot complain. Legal protection in the EU is considered below.

- In Latin America, IACnHR has been established in 1967 for the enforcement of ADRDM. IACtHR first convened in 1979 for the enforcement of ACHR, whereby 21 states accept its jurisdiction. The complaints procedures resemble those of the early European system [114]: if IACnHR finds a violation of the ACHR, it submits the case to IACtHR. For 14 states not accepting the jurisdiction of IACtHR (e.g., U.S.A.), IACnHR may investigate under ADRDM.

\subsection{Addendum on EU-Law}

EU is a supranational system. It combines elements of national institutions (states ceded powers to EU) and of treaty systems [115]. All 28 EU-countries (505 million citizens) are also Council of Europe members. The Charter of Fundamental Rights (2000/C364/01) reaffirms ECHR-rights and augments them by economic and environmental rights (e.g., Article 37 Charter mentions environmental protection).

Water supply and sanitation are the responsibility of member states, whence there is no HRW at EU-level. However, the preamble of the Water Framework Directive (2000/60/EC) about river-basin management comes close to acknowledging HRW [116]: water would not be a commercial product, but "a heritage which must be protected, defended and treated as such". Other directives command urban wastewater treatment (91/271/EC of 1991), limit water pollution by nitrates (91/676/EC of 1991), set quality standards for drinking and bathing water (98/83/EC of 1998, 2006/7/EC of 2006), or regulate environmental impact assessments (2011/92/EU of 2011).

EU-member states have to apply EU-regulations correctly. The EU-Commission monitors them. If a member state does not rectify an unlawful situation, the Commission may start an Article 258 TFEU procedure and request a decision by ECtJ. If ECtJ finds a repeated violation of EU-law, under $\S 3$ Article 260 TFEU it imposes a penalty payment with deterrent effect. The Commission may withdraw it from the due transfer payments to the state.

Individuals alleging infringements of EU-law are expected to seek redress at national courts. Under Article 267 TFEU courts may request from ECtJ an interpretation of EU-law. However, as this is left to the discretion of domestic courts, it cannot be ruled out that their decisions contradict EU-law [117]. Further, under Article 44 Charter of Fundamental Rights individuals may submit a petition to the European Parliament. They may also complain about domestic authorities to the EU-Commission, or turn to the EU-Ombudsman or the EU-General Court, if the Commission breaches EU-law. 


\section{Implementation of HRW}

\subsection{International and Regional Implementation}

A key aspect in international case-law was discrimination against members of a vulnerable population (indigenous populations, national minorities, refugees or illegal immigrants). In Europe, authorities ignored the needs of the Roma minority for better housing (Italy under ESC: \#61) or bowed to majority views (Slovakia under CERD: \#86). HRW may even turn against minorities, when it is invoked to solve water problems of large towns at the expense of indigenous communities (Peru under CCPR: \#77). In these and similar cases, governments were found to be responsible to protect vulnerable groups in access to water and sanitation. Similar protection was afforded by domestic courts, e.g., government obligation to provide indigenous populations with water (Argentina \#3); no redirection of water away from indigenous land (Mexico \#69); racial discrimination for denied water connections to a black community (USA \#109).

A substantial number of cases concerned prison-conditions and similar situations (refugee detention centers), where individuals completely dependent on the state were denied access to water (Belgium under ECHR: \#10; Panama under ACHR: \#75 Tunisia under CAT: \#98) or to sanitation (Angola under ACHPR:\#1; Grenada under ACHR: \#40) or they were provided access that was not culturally acceptable (Russia under ECHR: \#84). Treaty bodies found degrading treatment, except under CCPR, where Article 10 applies (Zambia \#111; even under life threatening circumstances: Spain \#90).

For irregular settlements on public land, encroachers cause pollution (open defecation), as they lack water and sanitation services (a large fraction of the population in developing countries); they may even be legally excluded from such services (Israel \#55). Authorities were made responsible to strike a fair balance between conflicting HR-interests: pollution control to protect the health of the neighbors and respect for the property and life-style of those affected by government action. For instance, where long-established irregular settlements of vulnerable minorities (Roma in Europe) were a source of pollution, authorities should help them in finding alternative accommodations prior to the demolition of their shacks (Bulgaria \#17, Greece \#37 under CCPR; similar Bulgaria \#18, France \#33 under ECHR). Also domestic courts found HR-violations, where authorities razed irregular settlements to the ground (Bangladesh \#9, India \#51, Kenya \#64, South Africa \#89).

Another large group of cases concerned externalities by massive pollution and over-extraction from unsustainable water use by private actors, mainly industry. International and domestic case-law protected individuals.

- In Asia, for several countries (Bangladesh \#6, India \#48, Israel \#55, Nepal \#70, Pakistan \#74, and Philippines \#78) individuals could successfully claim constitutional protection against pollution.

- In Africa (Kenya \#63, Nigeria \#73 under ACHPR) and the Americas (Brazil \#15, USA \#107 under ADRDM; Canada \#21 under CCPR; Ecuador \#29, Suriname \#94 under ACHR) treaty-bodies made governments responsible for pollution that deprived indigenous populations from access to water; governments ought to ensure their participation in water-related decision-making and conduct environmental impact assessments. Also domestic courts confirmed this (Canada \#22; Chile \#24; Costa Rica \#26). However, there were concerns that IACtHR assessed the right to health in terms of its progressive realization only, making individual litigation difficult [118]. 
- Under ECHR, in Europe individuals could successfully claim private life intrusions by health impacts from industrial pollution, if of proven severity (Bulgaria \#19). ECtHR made governments responsible to inform and protect the population (Seveso dioxin disaster in Italy \#57; Baia Mare cyanide spill in Rumania \#82); support those affected from unavoidable pollution to move away (Russian steel works \#85; Spanish tanneries \#91; Ukraine coal mining \#104); ensure compliance of local authorities and industry with relevant regulations, including for risk and environmental impact assessment (exploding landfill in Turkey \#102; hazardous waste treatment plant in Italy $\# 58$ ); guarantee certain procedural rights (Sweden \#95: access to court for challenging the licensing of a water polluting waste dump) and the right to enforcement of court decisions in due time (Rumania \#82: reopening a water connection; Turkey \#101: discontinuing gold mine operations without permit). Also environmental organizations may participate in decision making (Belgium \#11) and public discourse is encouraged (France \#30; Latvia \#65). Similar obligations follow from ESC and in some aspects from EU-regulations (e.g., river water pollution: Greece \#39, Luxembourg \#67).

However, HR-treaties address private actors only indirectly insofar, as states have a positive obligation to protect, i.e., to regulate the conduct of private actors. Thereby states are flexible in their means [119]. In particular, for mining industry water is a key business asset, but the HR-implications of its use were not fully taken into account [120]. Indigenous populations were found to be particularly vulnerable. Also tourism industry pretended wildlife protection to relocate indigenous populations; this (and e.g., diamond mining: [121,122]) put pressure on the San People in Angola, Botswana (\#14), Lesotho, Mozambique, Namibia, South Africa, Swaziland, and Zimbabwe. Another issue was excessive water use by food industry: Coca Cola (India \#44) and Nestle (Bangladesh \#7) about over-exploitation; Mc Donald's (United Kingdom \#105) about muzzling critical NGOs.

Some kind of "direct corporate responsibility" towards HR is hardly to be found: There exist certain extrajudicial mechanisms on the basis of legally non-binding and non-enforceable recommendations. Examples are the OECD Guidelines for Multinational Enterprises [123,124] or, in Latin America, the "Tribunal Latino Americano del Agua" [125]. This tribunal was established by a civil society movement. Experts work out recommendations to resolve water-related complaints. It thus appears that more self-restraint of industry may be needed, such as voluntary adherence to corporate social responsibility guidelines and to sustainability standards [126].

Summarizing, HRW-litigation was successful, where it could invoke non-discrimination and respect for civil rights [127]. However, affordability relates to the fulfillment of HRW as a social and economic right [128]. Here, progressive realization and flexibility of states in their means to protect or fulfill HRW [119] makes litigation difficult. Thus, a lawsuit to enforce the provision of certain amounts of water to the poor at no costs was not successful (South Africa \#88). However, this does not imply that the state obligation to provide affordable access to piped water at home will remain a mere aspiration. Rather, HR-treaties are "living instruments" (for ECHR: [129]) and case law under e.g., the Optional Protocol to CESCR has yet to develop. In a case under ESC (similar to CESCR) litigants could prove the failure of the progressive realization of HR (France \#34): For large-scale social problems, governments are obliged to respond, e.g., to develop programs to provide homes with piped water at reasonable costs (similarly for problems affecting specifically a national minority: Italy \#61). Conversely, government 
obligations from HRW define public interests that may justify restrictions of other fundamental rights, in particular of property rights: Under ECHR (Belgium \#12), property rights should not always take precedence over environmental protection. Under CCPR (Austria \#5) there were no concerns that users had to pay high connection charges (half an annual median income) for water and sanitation infrastructure. In HRW-countries disconnections of the poor for non-payment of water-bills in general were unlawful (Argentina \#3, Brazil \#16, Venezuela \#110), but not always (Colombia \#25: disconnection as response to water theft; France \#35: municipalities may not prohibit disconnections; Netherlands \#72: disconnection for not paying 2000 EUR water bill; South Africa \#88: automatic disconnection, if more water is used than paid).

\subsection{Domestic Implementation: Classification of HRW-Countries}

It is a typical task of governments to organize water provision facilitated by water-laws and regulations [130]; typically municipalities are obliged to create and maintain water distribution and sewer networks (e.g., Finland: Section 6 Water Services Act). Thereby, at the grassroots level HRW is accepted across the world [131,132]. Thus, it is not uncommon that water-laws include social aspects. An example is social pricing for water or priority for drinking-water provision in the case of emergencies or draughts. Also, court-orders prohibiting arbitrary disconnections were not necessarily based on HRW (Malaysia \#68: non-payment of excessive charges due to defective meters). Further, since the 1990s international sponsors of projects in developing countries have promoted HR-based approaches. They focus on user participation, nondiscrimination, and information dissemination [133]. Thus, it is difficult to keep track of countries acknowledging HRW and to distinguish, how their regulations and practices differ from provisions that "merely mitigate the ecological damage inflicted by industrial economies" [134].

In view of this difficulty the paper defines that for an HRW-country in its self-perception HRW is accepted in national law or policies. Table A3 in the Appendix lists these countries and distinguishes between domestic implementation depending on the political will of the legislator (implementing HRW as a constitutional right or as a simple law), judicial activism by courts (deriving HRW from other fundamental rights, e.g., right to life), or government policies and declarations.

\subsection{India: HRW as an Implied Fundamental Right}

India is exemplary for countries, where domestic courts derived HRW from other fundamental rights. $\mathrm{SCt}$ has jurisdiction over $1 \frac{1}{4}$ billion citizens in 35 states and territories. It developed a liberal interpretation of the right to life (Article 21 Constitution of 1950) to derive HRW. Other relevant provisions were the state obligation to promote a decent standard of living (Article 47) and environmental protection (Article 48A). Litigation was successful against depletion and severe pollution of water. A data base [83] lists more than 1200 cases at different levels of jurisdiction under the key-phrase "right to water and sanitation".

With respect to secure drinking water provision [37,135], SCt derived HRW already in 1983 and was also concerned about overexploitation of water-bodies, repeatedly referring to the "public trust doctrine" [136]. The Bhopal disaster put pollution into the focus and SCt developed jurisdiction on the precautionary and polluter-pays principles. Consequently, drinking-water safety and environmental protection were deemed as more important than, e.g., safety concerns (about dams: \#45), cultural rights 
of indigenous populations (\#52; a similar situation under ACHPR deciding for cultural rights: Kenya $\# 63$ ), or property rights of encroachers (\#50, but differently for large scale evictions: \#51; cf. similar situations under ECHR: Belgium \#12 deciding against and Italy \#60, Turkey \#99 for encroachers).

In order to implement HRW, India has framed national water and sanitation policies, set up water-related institutions, and launched funding programs (e.g., Total Sanitation Campaign, operating since 1999). The National Urban Sanitation Policy of 2008 and related state policies aim at the eradication of open defecation. In 2010, a National Green Tribunal has been established for the speedy settlement of environmental disputes; it allows individuals to claim compensation for pollution or the violation of any other "legal right relating to environment".

However, there remain issues about certain societal discrimination. For lower castes, there is a de facto segregation in rural India that contradicts the provisions of the Indian Constitution and the Protection of Civil Rights Act of 1955 [137]; also internally displaced and refuge families suffer from lacking access to water [138]. There is also a high rural-urban discrepancy in access to water [139].

With respect to affordable access to water near the home, the government [140] and SCt (\#53) consider HRW as an obligation to ensure progressive realization, only. Rural municipalities typically charge a small water tax per tap in a household (see below), and some metropolitan cities (e.g., Bangalore, Chennai, Hyderabad) introduced metering, where the first 10 to $25 \mathrm{~m}^{3}$ per month were supplied at a very low tariff, intended to support the poor [141]. Yet up to $60 \%$ of meters were not working and typically the poor were without access to tapped water. Thus, in Bangalore, Karnataka state, the poor pay 50 INR/kiloliter for water from the tanker (60 INR - 1 USD), and the affluent $36 \mathrm{INR} /$ kiloliter for tapped water [142] (in the USA [143], 2011 costs per kiloliter were between 0.17 and 0.79 USD-10 to 48 INR).

The situation in two medium sized towns of Madhya Pradesh state, India, illustrates the challenges for improving water and sanitation services. City sanitation plans prioritized the rehabilitation the Lalbagh area of Burhanpur, an industrial town with 211,000 residents (2011) and the Mishra Talaab area of Raisen, a rural municipality with 36,000 residents (2001). These neighborhoods suffer from open defecation problems related to insufficient access to water, toilet facilities, and sewers [144,145].

WTP-surveys by the authors found that median WTP (including water tax) for public service improvements was 70-100 INR/month in Burhanpur and 115-160 INR in Raisen (one-sided 95\%confidence-limits). Water tax was 50 respectively $60 \mathrm{INR} / \mathrm{month}$ per tap. This outcome was comparable to other studies from India. For instance, residents of Mumbai, Maharashtra, were willing to accept 51\% cost increase for better water provision [146]. The estimation of expected revenues assumed a combined water and sanitation charge, based on 500 households served (about 3000 people). For revenue maximization, optimal user-charges were about $100 \mathrm{INR} /$ month with revenues below 30,000 INR/month for each city [147].

Clearly, $500 \mathrm{USD} / \mathrm{month}$ or less do not finance new infrastructure, but with Indian per capita median income of 616 USD annually [148] they may finance maintenance. Thus, public funding of the capital costs of water infrastructure for the poor is needed. However, also poor communities (though not all of their members) can be expected to contribute to the running costs. Indian funding guidelines reflect this; typically $90 \%-95 \%$ capital costs of rural water supply infrastructure are funded and users contribute the remainder and running costs [149]. 


\subsection{South Africa: HRW as an Explicit Constitutional Right}

South Africa is exemplary for countries, where HRW is an explicitly stated constitutional right [150]. The Constitution of 1996 (amended 2003) guarantees: "Everyone has the right to have access to sufficient food and water" ( $§ 1$ Article 27). However $(\S 2)$, the state is obliged merely to a progressive realization of HRW and case-law confirmed this. Also the right to health is acknowledged (Article 24).

South Africa implements HRW by a Free Basic Water Policy. It is based on the Water Services Act of 1997 and the Water Services Regulation of 2001. Households receive a free water allowance of $6 \mathrm{~m}^{3}$ per month (or more, depending on the city), but users are charged for excess demand. In a case study for the Rio Grande Basin, USA, such a two-tiered tariff system (low charges for basic water needs of households and efficient charges for discretionary use) has turned out to be most efficient [151].

However (other than in e.g., United Kingdom: Table A3), meters may automatically disconnect water supply, if more water is demanded than pre-paid. Alternatively, the city of eThekwini (Durban), South Africa, provided poor households with low-pressure systems to help them get along with the free basic water: For users, who illegally upgraded their system to full-pressure, water consumption became unaffordable [152].

This policy has been criticized, as it ignores household size and therefore would discriminate against large families that in general are poor [153]; $c f$. with regulations in Chile (Table A3), where households receive income dependent water subsidies. Subsequent litigation to define a minimum entitlement of free water per person and prohibit prepaid meters was turned down by the Constitutional Court (\#88): HRW is only a state obligation for progressive realization, conditional on budgetary constraints. Although the outcome was negative; the Court's reasoning showed openness for arguments similar to ESC (France, \#34). Further, in the context of the eviction of encroachers, the right to an adequate standard of living and tapped water was acknowledged (\#89).

\section{Cross-Country Comparisons: Did HRW Have Impact?}

There are conflicting views whether HRW has improved the situation of the poor (Section 2). This section reviews this issue for HRW-countries as a group, assessed under the perspective of performance indicators. It confirms, with a large data basis, that the acceptance of HRW "by itself may not help the poor to gain access to water and thus is not a magic bullet" [34].

Indeed, for dataset 1 there was a 95\% significant contingency (Fisher exact test) between HRW and low water provision: Most (33 of 52) HRW-countries had LPCD $<100$ in 2000, while most (76 of 124) not-HRW-countries had LPCD $>100$. Further, amongst countries with LPCD $<100$, LPCD was not stochastically higher for HRW-countries. For dataset 2, access to improved water was not stochastically higher for HRW-countries (23 HRW, 40 not-HRW-countries). Low water provision in turn was linked to geographical and governance aspects.

- Countries with low $(<100)$ LPCD had a stochastically higher RWH-potential than countries with high (>100) LPCD. That they nevertheless had low water provision may be due to common geographical factors: With 95\% significance countries with low/high LPCD were clustered (this means that there were more low-low, high-high and less low-high neighbor-countries than expected under randomness. Random simulations used the UCINET 6 function "categorical 
autocorrelation/join-count statistics"). Possible explanations may be monsoon (difficult to utilize for water provision) or arsenic in the easy to exploit shallow groundwater sources, which affects much of Asia [154].

- As to governance, for 29 of 30 indicators the performance of 81 countries with LPCD $<100$ was stochastically worse than that of 95 countries with LPCD $>100$ (dataset 1); religious freedom was an exception. Also within the group of 81 countries with LPCD $<100$, better governance (lower deficiency indicators) was linked to better water provision, with significant negative correlations (T-test) between LPCD and ten governance indicators.

- For three of these indicators (government effectiveness, regulatory quality and rule of law) there were significant negative/positive correlations both with water stress and r-LPCD, which seems to indicate that countries with more renewable water resources put less attention on good governance.

As to the question, why HRW-countries did not perform better, deficiencies could partially be explained by sharing the situation of countries with low water provision (most HRW-countries are in that group).

- Geography mattered for HRW, as HRW-countries were clustered (Figure 1), with significantly more pairs of neighboring HRW-countries than expected from randomness. This clustering was also observed, if controlled for low/high LPCD, whence the contingency of HRW with LPCD alone could not explain HRW-clustering. Rather, there seems to be a trans-boundary flow of the HRW-idea, carried e.g., by a grassroots-level water-movement in Latin America [155].

- For positive effects of HRW, amongst 81 countries with LPCD $<100$ the $33 \mathrm{HRW}$-countries performed better in the following aspects: There were significant negative correlations between HRW and deficiencies in effectiveness of government, regulatory quality and intervention of external actors (e.g., dependency on foreign aid) and HRW-countries had also a stochastically better performance in these indicators.

- However, amongst 95 countries of dataset 1 with LPCD $>100$, the 19 HRW-countries performed stochastically worse for extrajudicial killing, political stability, uneven development and deterioration of public services.

- Overall, comparing $52 \mathrm{HRW}$-countries with 124 other countries (dataset 1), HRW-countries suffered from stochastically more political instability, and related to it from stochastically worse ratings for extrajudicial killings, torture, political prisoners and group grievance. They also suffered stochastically more from demographic pressures, which in turn may explain the stochastically worse situation for HRW-countries with respect to deterioration of public services (including water and sanitation) and uneven economic development (e.g., slums with poor water services).

Dataset 3 specified these differences by a comparison of twelve non-HRW-countries with eight HRW-countries (four countries, Bangladesh, India, Nepal, and Pakistan, where courts derived HRW, and four countries, China, Indonesia, Philippines, and Sri Lanka, where HRW was stated in the constitution or accepted in other ways). Other than for dataset 1, compared to their region the Asian HRW-countries had stochastically higher levels of human flight and brain drain, factionalized elites struggling for power, and faulty security apparatus. 
- With respect to the indicator "legal format of surface water rights", on a scale between rather unclear rights (no, unclear, or multiple) and well-defined water rights (riparian, appropriative, correlative, licensing), HRW-countries had stochastically higher indicator values, i.e., HRW-countries (specifically those with court-derived HRW) tended to have unclear water rights or declared water as common/state property.

- Considering the indicator "pricing policies" for domestic, industrial and agricultural water uses, HRW-countries (specifically those with court-derived HRW), had stochastically higher indicator values than the other countries; i.e., higher subsidies for water. Clearly, in low-income countries there may be a need for such subsidies.

- With respect to "adequate financing", there was no stochastic difference for HRW-countries, but the seven countries with LPCD $<50$ in 2000 had stochastically higher deficiency values, indicating continued inadequacy of resource provision for new and maintenance of existing water infrastructure.

- The indicator "capability of the administration" evaluates, how water institutions care for planning and design of water infrastructure, its implementation, financial management, operation and maintenance, for rehabilitation and resettlement, environmental monitoring, research and training, and for interagency and departmental relationships. On a scale between "incapable with unbalanced functional specialization" and "capable and balanced", the deficiency indicator was stochastically higher for HRW-countries; i.e., these countries may suffer from rather incapable water institutions (observed for all countries with court-derived HRW). For instance, in Tamil Nadu state, India, stakeholders from the water sector complained about the fragmentation of administrative responsibilities and they asked for yet another authority, where water responsibilities would be amalgamated [156]. A state law would have foreseen this, but it was never notified and repealed in 2013.

With respect to the question, if the form of accepting HRW matters, data seem not decide the claim of [37], that HRW as a court-derived right would be less effective: for dataset 1, comparing ten countries with court-derived HRW with 42 other HRW-countries, there was no stochastic difference.

For dataset 3 (Asia), the four countries that accepted HRW as a constitutional right, law or policy were more favorable for user and private sector participation. Their water-policies were linked more closely to water-laws and to other policy fields (e.g., agriculture including soil conservation, environment and pollution control, or fiscal policies/energy subsidies). Policies were rather pro-poor and consequently required project selection to depend rather on multiple criteria. Accountability and regulatory arrangements imposed on water administration were more effective and administration was better prepared to use modern science and technology. However, this finding may be interpreted that institutional deficiencies may have forced courts to step in, derive HRW and improve water-governance. Higher water subsidies in Asian countries with court-derived HRW indicate that governments gave more priority to the affordability of water. 


\section{Analysis of Affordability}

\subsection{Water Conflicts}

Affordability has been the most contested aspect of HRW. In particular for Latin America, political conflicts about infrastructure privatization have driven the acceptance of HRW in domestic law [155]. In Bolivia increases of tariffs have stirred violent public protests that finally forced the municipalities of Cochabamba and La Paz to cancel contracts with international water companies [157] (subsequently challenged under ICSID). Conflicts related to water privatization occurred also in Argentina (\#2), Ghana and Tanzania [158], Nepal prior to the entry of Communist parties into government [159], or South Africa $[8,160]$. Problems with privatization were reported also from the USA and the Philippines, where privatization continued [161]. Proponents of HRW asked for a reversal of privatization, demanding in effect environmental justice, as compared to their income the economic and environmental burdens for the poor would be out of proportion [162]. Further, negotiation of privatization (e.g., concession contracts) was criticized for its "opaque method" and corruption [163].

However, HRW is not incompatible with privatization [164], as private-sector-participation (business models: [165]) may support HRW by service improvements that in turn would justify moderately higher tariffs. For, even assuming that private investors were basically interested in revenue maximization (aiming to charge users higher opportunity costs), by data for Argentina and Chile productivity of privatized water and sewerage companies initially increased due to technical improvements [166,167]. Also a comparison of 308 cities in 102 countries concluded that low water tariffs are not necessarily pro-poor, as lower tariffs tend to go with a higher risk of shortages [143], i.e., water services of poorer quality. For, where public water service providers aimed merely at recovery of supply costs (capital costs for construction, running costs for operation and maintenance), service improvements were difficult to finance. Therefore, international financiers of development programs suggested more user participation in cost sharing [168,169].

With respect to affordability, data for the USA confirmed that privatization of water services did not reduce costs [170]. Another analysis of 12 countries indicated that public or private management would on average not make a big difference and possibly unaffordable tariffs (more than $3 \%$ of household income for water services) were found only for public utilities in two HRW-countries, Bolivia and Uganda [171]. Further, users would be willing to pay more for piped water [172]; up to $2 \%-8 \%$ of household income in slums of Mexico [173].

An alternative explanation for conflicts about allegedly unaffordable tariff increases may be a peculiar WTP-distribution (an aspect not considered hitherto), as illustrated for Figure 2. It displays expected revenues for a log-Cauchy distribution of WTP. The cumulative distribution function for WTP $>0$ is $\operatorname{CDF}(x)=0.5+\arctan ((\log (x)-m) / s) / \pi$ (here, $\arctan$ is the arctangent and log the natural logarithm.). The expected revenue from charge $x$ (no service for users with lower WTP) is $x \times(1-\mathrm{CDF}(x))$. There is a local maximum for small user charges ( $c a .100 \mathrm{INR}$ ), i.e., a low-cost solution with running costs financed by a large crowd. It is typically preferred by communal utility providers (e.g., stand-posts rather than piped water for each household). However, there are infinite expected revenues from infinite user charges, as for $x \rightarrow \infty$ also $x \times(1-\mathrm{CDF}(x)) \rightarrow \infty$. This forecasts that for any more advanced and more costly infrastructure (e.g., reverse osmosis) there are few, but enough users with high WTP for financing it. For 
a private utility provider this may be an incentive for service improvements, which require high user charges that possibly exclude the poor from services. Thus, a peculiar WTP alone might explain, why privatization of hitherto low-cost communal utility services would generate pressures for tariff-increases.

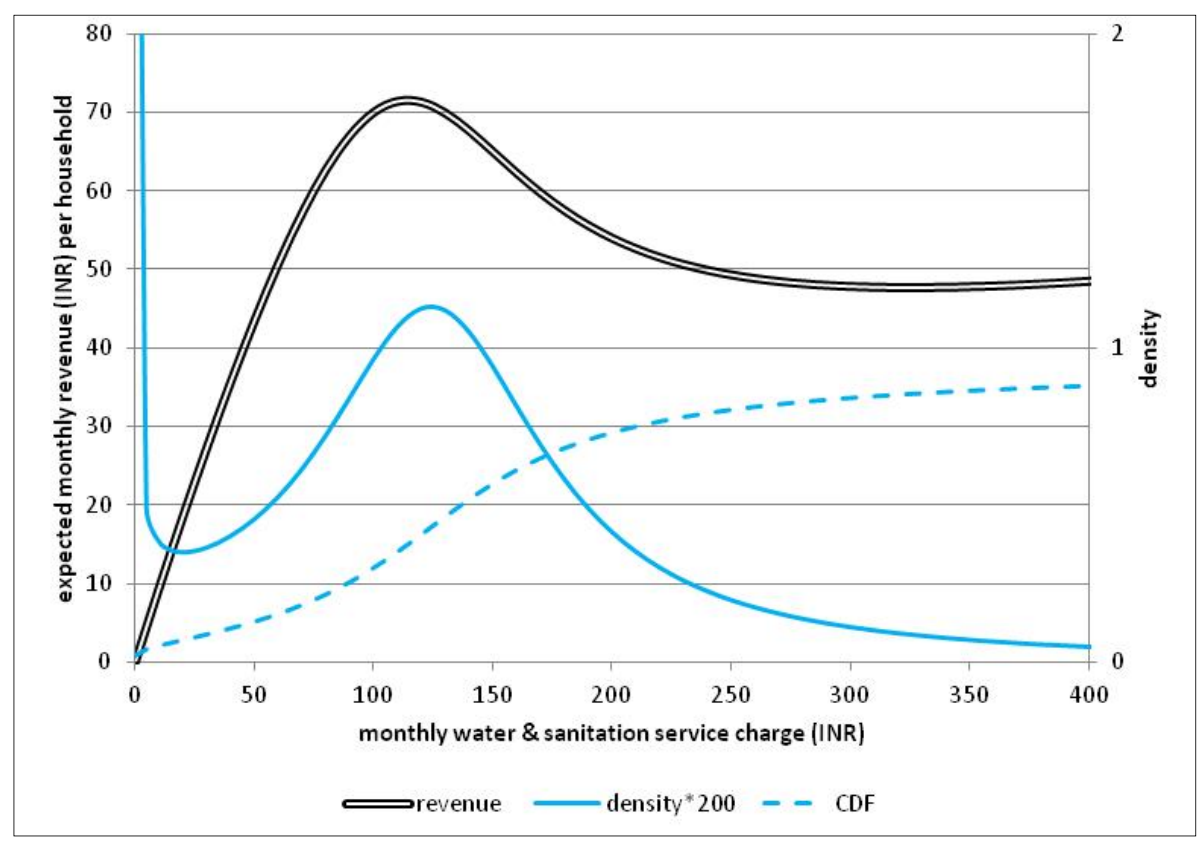

Figure 2. Optimizing water tariffs, if willingness to pay (WTP) $>0$ follows a log-Cauchy-distribution; Notes: $\log (\mathrm{WTP})$ is Cauchy-distributed with median $m=4.92$ and scale parameter $s=0.43$ (parameters $m, s$ are maximum likelihood fits to survey data by the authors from Raisen, Madhya Pradesh, India. Acceptable fit was confirmed with Mathematica 10 simulations of the Cramér \& von Mises test).

The same peculiarity may be observed in different poverty-related fields: The rural population around Darjeeling, West Bengal, India, had 200 INR median WTP for optimal diarrhea-treatment in a public hospital [174], compared to 1000 INR average physicians' fees per routine consultation [175].

A log-Cauchy-distribution is insofar peculiar, as in environmental economics [146,174,176,177] traditionally normal (probit model), lognormal, logistic (logit model), log-logistic or Weibull distributions were assumed; economic theory considered also Cauchy and t-distributions with infinite moments [178]. However, these distributions had a poor fit for the survey data.

\subsection{Modeling Funding Policies}

There is an ideology driven debate about public funding, e.g., as there are concerns about market-distortions from subsidies and possible beneficial spill-over effects from subsidies to innovators [179]. Thus, in many developing countries farmers receive energy subsidies (electricity and gasoline for pumps), which some authors linked to over-exploitation of groundwater for irrigation [180]. (Beyond energy subsidies, there are many other factors linking irrigation and drinking water supply. It is not the focus of this paper to explore them.) Community-led total sanitation has been proposed as an alternative to public funding. However, World Bank concluded that this alternative would work better with public funds, based on case studies in India and Indonesia [181]. In a legal context, General 
Comment 15 about HRW under CESCR made it clear that public funding is amongst the suitable instruments to fulfill HRW.

Governments funding water-infrastructure for the poor face two potentially conflicting goals, support for the poor and economic use of public money. On the one hand (economy of scales), larger centralized capital-intensive systems cost less per user [182]. On the other, revenues for water infrastructure services are low relative to capital costs [183], whence poor communities can barely afford large infrastructure. Further, in rural regions per capita infrastructure costs are particularly high (e.g., longer water lines for fewer people), explaining the typically lower access-rates to safe water in rural regions [184].

Therefore, in view of its high costs, water and sanitation infrastructure may need public support, but there is also an obligation for the beneficiaries to maintain it. A conflict between these goals arises, if the beneficiaries are too poor to afford the infrastructure; this may be described in terms of efficiency. Society may resolve the conflict by a compromise, which supports also less needy users, who then contribute to the maintenance. In addition, funding may be backed by management support to enhance efficiency.

A linear programming model describes the range of possible policies in terms of program efficiency of funding. It models policy compromises by the sharing of public funds between two groups of potential beneficiaries:

- $\mathrm{N}$ denotes poor and therefore potentially inefficient users. They may be too poor to afford the infrastructure and therefore be non-compliant, leading to losses of funds by shortened lifetime, stranded investments, or corruption [185]; e.g., communities asking contractors to charge higher costs from the funding institutions and share the gain with them [149].

- S denotes compliant users, who contribute their cost share as per guidelines. They are fully efficient (ignoring random inefficiency, if, e.g., a source produces less water than projected), but as they may be better off (or can take loans to pay more), for them a lower funding rate might suffice. For instance, a total sanitation campaign of Orissa state, India, subsidized the poor, only [186]. A related concept is income-dependent subsidies directly to households (e.g., Chile, Table A3).

- In addition, there are costs for management support. For example, if budget estimates of contractors are carefully screened, then corruption becomes less likely, but there are costs for audits and external inspection (ensuring that funded infrastructure actually exists and is operational). The provision of improved sanitation facilities may need hygiene education of users to become effective [187]. Also upgrading of incapable water institutions (Section 6) and education of local staff may be helpful. To promote drinking-water security, administrative and regulatory measures may be needed to restrict uncontrolled extraction from groundwater sources.

The paper distinguishes the following aspects of efficiency (modeled as cost-efficiency).

- Program efficiency is costs per unit of service from the perspective of society (represented by the funding institutions): $e=m / c$, where $m$ is the baseline per capita funding, by which society could ensure a certain benefit (infrastructure with certain characteristics) and $c$ is the actually needed or projected per capita funding. Inefficiency $(c>m)$ may arise due to a reduction of benefits: Inadequate maintenance causes shorter life time and new infrastructure funding is needed earlier than planned. 
- Project efficiency (efficiency from the local point of view, i.e., a planner) compares alternatives with different costs and benefits. Benefits (e.g., social, environmental) are measured by some index and efficiency relates the projected costs $c$ to the projected benefits.

- User efficiency measures (in relation to program efficiency) what fraction of expected benefits is reached for users $\mathrm{S}$ and $\mathrm{N}$, using indices $e s$ and $e_{N}$. By the definition of $\mathrm{S}$, funding is efficient for $\mathrm{S}$; $e_{S}=1$. For $\mathrm{N}$, the efficiency $e_{N}$ of funding varies between 0 (maximal corruption: users take the money and go) and an optimum level $l_{N} \leq 1$ : If users cannot afford professional servicing, then $l_{N}<1$, as the infrastructure may become defunct earlier. Consequently, funding may waste a certain fraction of the support for the poor, namely not attained benefits $w=\left(1-e_{N}\right) \times x$.

Funding policies are modeled by equations (1) and (3-5) that refer to policy restrictions and by (2), a hypothesis about efficiency-effects of management support.

$$
\begin{gathered}
x+y+z=B \text { and } x, y, z \geq 0 \\
e_{N}=a \cdot \frac{z}{x}, \text { if } \frac{z}{x} \leq \frac{l_{N}}{a}, \\
\text { and } e_{N}=l_{N} \text { if } \frac{z}{x}>\frac{l_{N}}{a} \\
\frac{z}{x} \leq \frac{l_{N}}{a} \\
\frac{e_{N} \times x+y}{B} \geq e_{\min } \\
\frac{x}{B} \geq p_{\min }
\end{gathered}
$$

The model equations are motivated as follows: Equation (1) says that a budget $B>0$ for funding water or sanitation infrastructure is split into $x \geq 0$ for $\mathrm{N}, y \geq 0$ for $\mathrm{S}$ and $z \geq 0$ for management support. Alternative budget assumptions, e.g., $B<0$ and $x<0$, are conceivable, but not considered here. This would describe e.g., the policy of al-Shabab militia ruling part of Somalia: It diverted water from subsistence farmers to profitable enterprises under its control [188], which aggravated the famine of 2011.

Management support $z$ (in addition to management expenses needed for all users) increases user-efficiency $e_{N}$. For simplicity the model assumes a piecewise linear index (2). By this condition, each rupee for supporting measures reduces losses by $a$ rupees (the multiplier, $a$, is a constant). The model assumes $a>1$, as otherwise enhancing measures would be wasteful. Further, by this condition, management support is limited: When the maximal level of efficiency is reached, any additional spending would by excessive (slack). Thus, in view of (2), the model assumes condition (3).

Society may monitor the overall efficiency of the provided funds (secured benefits relative to the budget $B$ ) and their contribution to poverty abatement (rate of the funding to $\mathrm{N}$ ). Society may thereby prescribe thresholds $e_{\min }$ for the minimal overall efficiency and $p_{\min }$ for the minimal rate of funding to N. Thus, two more conditions enter the model for policies to be acceptable to society, (4) and (5). 
Figure 3 plots the model for "endurable poverty", which is characterized by the feasibility of allocations, which give all funds to the perhaps most needy users $\mathrm{N}$ (line segment between $\mathrm{A}$ and $\mathrm{B}$ on the $x$-axis). This situation is typical for national policies. Thus, efficient users may receive funding, but policies may decide otherwise. Other situations are notable, too: In the case of most extreme poverty, some funds have to be provided to perhaps not needy users S in order to secure total efficiency; there A and $\mathrm{B}$ coincide above the $x$-axis (inevitable high inefficiency of the poor: small $l_{N}$ relative to the other factors). A different figure arises, if $\mathrm{C}$ and $\mathrm{D}$ coincide below the budget bound (high $p_{\min }$ or $e_{\min }$ ).

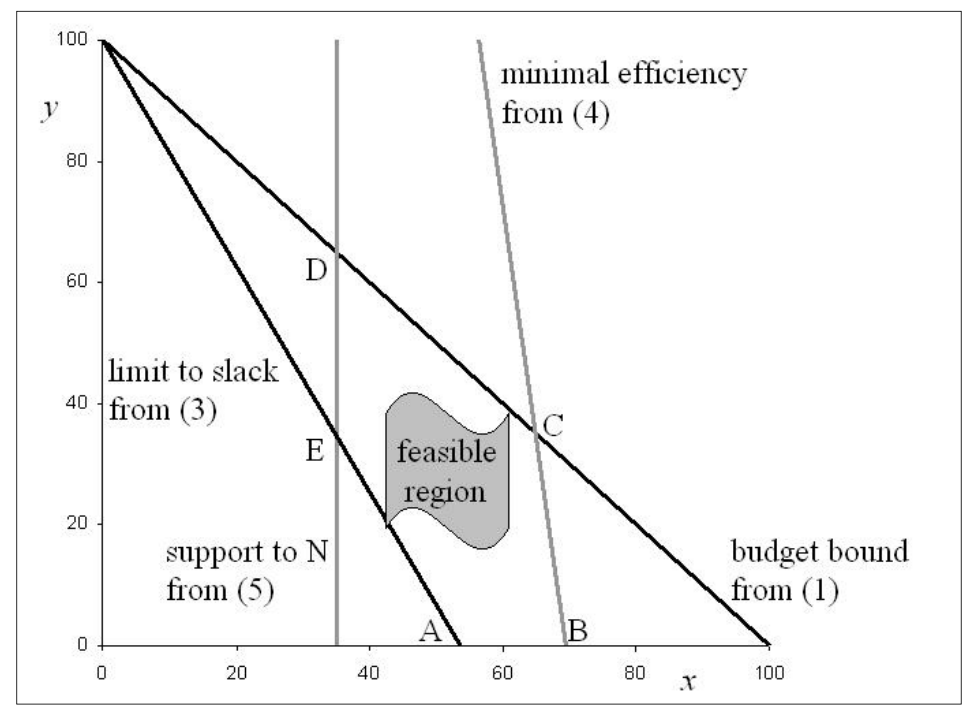

Figure 3. Potential social optima, A to E; Notes: The figure plots the case of endurable poverty (policy is free to fund the poor, only).

\subsection{Policy Goals}

States that fund infrastructure for the poor to progressively implement HRW will choose funding-policies that are practical in their situation. In order to distinguish promising policies from policies that have been tried in the past and resulted in failures, the mathematical model is used to characterize policies in terms of their goals. In the model, an idealized goal is interpreted as a linear optimization goal over the feasible region (Figure 3), defined by the model equations. It defines a point on the boundary of the feasible region. In terms of Figure 3, the model explains ten policies towards the progressive realization of HRW.

Goal 1: Maximize overall benefits of funding, $e_{N} \times x+y$; i.e., maximal program efficiency $=$ left term in (4). This goal is achieved at $\mathrm{E}$ (also in the degenerate cases $\mathrm{D}=\mathrm{E}$ or $\mathrm{A}=\mathrm{E}$, when $p_{\text {min }}$ vanishes or is large). Thereby, funding concentrates on the efficient users $\mathrm{S}$ and keeps support for problematic users $\mathrm{N}$ at the minimal desired level $p_{\min }$. Management support allows them to make fair use of the funds. However, funding institutions may generate bureaucratic slack by providing too much management support (higher $z$ moves the solution towards A = goal 3), as then overall support for the poor would be higher, than wanted by society.

Goal 2: Maximize local efficiency, i.e., $e_{N} \rightarrow \operatorname{Max}$. $\left(e_{S}=1\right)$. This ensures that supported needy communities $(\mathrm{N})$ make the best use of infrastructure possible to them. There are two cases: 
(i) If $\mathrm{A} \neq \mathrm{E}$, then this goal is achieved on the line segment between $\mathrm{A}$ and $\mathrm{E}$, the boundary $e_{N}=l_{N}$ between unjustifiable slack and helpful management support. A secondary goal (minimal or maximal support to the poor) then characterizes a unique policy (E or $\mathrm{A}$ ); (ii) If $\mathrm{A}=\mathrm{E}$, then $\mathrm{A}=\mathrm{E}$ is the optimum also in case $e_{N}<l_{N}\left(x=p_{\min }\right.$ is minimal and $z$ is maximal, whence also $z / x$ is maximal).

Goal 3: Maximize benefit of the overall support for the poor (roughly N), i.e., their successful support. This means, $e_{N} \times x=a \times z \rightarrow$ Max. Equivalent goals are maximizing management expenses, $z$, and minimizing $x+y$. This goal is achieved at A. It should be noted that despite $z \rightarrow$ Max, funding under goal 3 does not generate bureaucratic slack, which differs from conventional wisdom [189]. For, with this goal society (the principal) turns the self-interest of its agent (funding bureaucracy) to its own advantage: Both society (by goal 3) and funding bureaucracy have the same interest (the latter in maximizing $z$, as with a fixed funding budget a higher $z$ increases the influence of the bureaucrat allocating $z$ ).

Goal 4: Minimize wasted funds $w$; i.e., $w=\left(1-e_{N}\right) \times x \rightarrow$ Min, as only funds for $\mathrm{N}$ can be wasted. Other goals are similar: At the project level, minimization of wasted funds is goal 2 . At the strategic level, minimization of wasted funds may also mean $x=p_{\min }$, which is goal 8 (line segment between $\mathrm{D}$ and $\mathrm{E}$ ). For goal 4 there are three cases: (i) If $l_{N}=1$ and $\mathrm{A} \neq \mathrm{E}$, then $w \rightarrow$ Min on the line segment between $\mathrm{A}$ and $\mathrm{E}$; a secondary goal defines a unique policy (A or $\mathrm{E}$ ); (ii) If $\mathrm{D}=\mathrm{E}\left(\right.$ i.e., $p_{\min }=0$ ) and $l_{N}<1$, then $w \rightarrow$ Min is achieved with $x=0$ at $\mathrm{D}=\mathrm{E}$ (goal 8); (iii) Otherwise (i.e., typically), $w \rightarrow$ Min is equivalent to $e_{N} \times x \rightarrow$ Max, achieved at A; this coincides with goal 3 .

Goal 5: Maximize direct support to the needy poor $(\mathrm{N})$, i.e., $x \rightarrow$ Max. It is achieved at $\mathrm{B}$. In the case of extreme poverty $(\mathrm{A}=\mathrm{B})$ it coincides with goal 3 . If society does not ask for efficiency, $\mathrm{B}=\mathrm{C}$ and $x=1$ (all funds go to $\mathrm{N}$ and may be lost). However, in the case of endurable poverty $\mathrm{A} \neq \mathrm{B}$ bureaucratic slack could occur, as the funding institution may be more cautious in the direct support of the poor, than society, and rather provide more management support (higher $z$ moves the solution towards $\mathrm{A}=$ goal 3).

Goal 6: Maximize direct and indirect support $x+z$ to the needy poor $(\mathrm{N})$. Equivalent is minimization of support to $\mathrm{S}$, i.e., $y \rightarrow$ Min, as supposedly affluent users may not need support. In the case of extreme poverty, this goal is achieved at $\mathrm{A}=\mathrm{B}$. In the case of endurable poverty, each point on the line segment between $\mathrm{A}$ and $\mathrm{B}$ solves $y=0$; $\mathrm{a}$ secondary goal (minimal/maximal program efficiency) defines a unique policy (B or A).

Goal 7: Concentrate support to efficient users $\mathrm{S}, y \rightarrow$ Max (this is different from goal 1 and complementary to goal 6 .) The problematic users $\mathrm{N}$ are only funded and supported at the

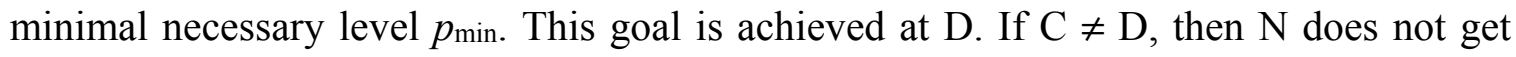
management support $(z=0)$. In case $\mathrm{C}=\mathrm{D}$ some management support for $\mathrm{N}$ may be necessary to fulfill high standards $e_{\min }$ of program efficiency (4).

Goal 8: Minimize support of problematic users N, $x \rightarrow$ Min. (This is different from goal 7.) It is achieved on the line segment between D and E. A secondary goal (e.g., minimal or maximal management support) then defines a unique policy.

Goal 9: Minimize management expenses, $z \rightarrow$ Min. (This is not minimizing bureaucratic slack.) This is the same as maximizing the amount of directly distributed funds, $x+y \rightarrow \operatorname{Max}$, and 
roughly the same as the maximization of the number of beneficiaries (who may be voters). If $\mathrm{C} \neq \mathrm{D}$, then this goal is achieved at any point of the line segment between $\mathrm{C}$ and $\mathrm{D}$ (where $z=0$ ). A secondary goal (e.g., minimal or maximal funding of the very poor) defines a unique policy. If $\mathrm{C}=\mathrm{D}$, then management support $z$ is minimized there, but needs not vanish.

Goal 10: Maximize expenditures that are not directly related to the intended benefit, $w+z \rightarrow$ Max, where $w=\left(1-e_{N}\right) \times x$ are the wasted funds. Equivalent is the minimization of the (water related) efficiency (4), which is achieved on the line segment from B to C. Secondary goals then define a unique policy. A deliberate misappropriation of public funds can be a rational goal. For instance, failure of funding may be likely for other reasons, but beneficiaries are known to utilize the funds for societal important purposes (e.g., rural development). Also excessive management support $z$ to build up capacity may create local jobs and have beneficial long-term effects (e.g., more democratic village structures). In sanitation funding, abandoned toilets (wasted funds $w$ ) benefit villagers, who prefer open defecation and use defunct buildings as storage sheds or barns.

Environmental protection is an example for a goal that is not considered by the model (an issue for sanitation). However, in developed countries environmental policy goals are already defined and laws may command that users connect their homes to a municipal sewer network, and that the municipality in turn treats the sewage according to prescribed standards [190]. Thus, an additional environmental dimension may not be needed. In developing countries industrial pollution is the dominant problem. Hence in an initial analysis additional environmental goals of sanitation need not be analyzed.

\subsection{Actual Policies for Ensuring Affordability}

In terms of the idealized policy-goals, certain actual policies can be characterized.

- Past supply-driven approaches in developing countries may be characterized by goal 5, which charitably supported the poor, but then left them alone with infrastructure, which they could not maintain, resulting in stranded investments. Lack of management support (and ignoring local demand) has been a structural problem. For instance, a survey of 15 villages in rural Northern Ghana found 39\% of funded VIPs (ventilated pit-latrines) abandoned by the users [191], depending on the supporting NGO (failure rates 6\%-59\%). But also with demand-driven policies insufficient maintenance remains a problem for municipal water infrastructure [192].

- Channeling public support to the most promising projects, typically to the efficient users in economically better off urban regions (goal 7), has been another response to massive infrastructure needs. It has aggravated the urban-rural disparities [184]. Rural villages were not ignored (though also there funding may have focused on the better-off households [191]), but the funding institutions may have been too remote to ensure efficiency (goal 8 with minimal management support).

- Also voter maximization has been a motive (goal 9). For instance, in Nepal political parties exerted extreme influence on all aspects of life [193]. The case of the Marsyangdi River Bridge in Lamjung District is notorious, where in 2008 despite shortage of funds each major party requested a bridge for its own clientele [194]. 
- There remain two policy approaches, which are characterized by local efficiency (goal 2), the maximal overall benefit of the funded projects (goal 1) and the successful support of the poor (goal 3). Both funding policies are compatible with HRW.

- In support of the latter policies, participatory planning of infrastructure and involvement of civil society and supporting organizations has increased the awareness of local beneficiaries for more sustainable solutions [195], making management support more efficient. In terms of the model, these policies control the multiplier, $a$, of formula (2): More civil society involvement may be described by a larger multiplier (it moves A and B in Figure 3 to the right). With goal 3, a larger multiplier allows to give more direct support (more projects) to the very poor $(\mathrm{N})$. With goal 1 , for a larger multiplier (E moves up) management support $z$ could be decreased, while the rate of direct support to the poor remains the same (i.e., more support for $\mathrm{S}$ and $\mathrm{N}$ ).

- The same effect (higher multiplier $a$ ) may be achieved by pro-women policies (mobilize women, change societal attitudes towards women). Water provision (compared e.g., to better roads) in general has a higher priority for women than for men [196]. This affects both water-related decision-making at the local level (allocation of communal funds) and within families (WTP) and may make management support more effective.

The successful support of the poor (goal 3) coincides with goal 2 (maximal local efficiency) or goal 4 (minimal lost funds) plus maximal support to the poor. Thus, if efficiency-oriented funding programs successively facilitate access to funding for the poor, by allowing them e.g., in-kind contributions, then this is an indication of their wish to maximize support to the poor without sacrificing efficiency. Also goal 6 (maximize direct and indirect support to the poor) reduces to goal 3, if it starts from support to the poor and is successively made more efficient.

Clearly, goal 3 by definition fulfills the HRW-obligation of "prioritizing essential levels of access to the most marginalized" [197]. The policies of the HRW-states India and South Africa apparently follow this goal: In India successive government programs increased management support [149]; this is an indication for the application of goal 3. In South Africa, the provision of free basic water supports the poor and user charges for excess consumption ensure rational use of water.

The maximal overall benefit of the funded projects (goal 1) coincides with goal 2 (maximal local efficiency) combined with goal 8 (minimal support to the poor), respectively goal 8 combined with high management support. An example is Austria, where a funded wastewater system has to be part of an optimal solution at a larger catchment's level, where either a commercial utility provider takes responsibility or where several villages cooperate [190]. A sub-optimal stand-alone solution of a poor peri-urban village receives no funding, even if from the village perspective it would cost the users of the village less [198]: Some villages have been better off to build their own system without funding, causing higher costs to their neighbor communities (they, too, must build some system.)

Also goal 1 may have indirect benefits for poor users, as it supports better planning, which saves costs. However, in the context of privatization (goal 1) this benefit may diminish due to excessive user charges by water companies (e.g., Latin America). Also communities may earn more in user charges for water and sanitation services than they earmark for infrastructure maintenance; this happened in Austria [199]. As states enjoy much flexibility in interpreting HRW [119,200], also goal 1 may be compatible with HRW: There are no HR-concerns about lawful regulations that impose limitations upon 
HRW, as long as the limitations purse a legitimate aim, are proportional to these aims and do not impair the very essence of HRW. Therefore, a state aiming at economic sustainability of water services may require the poor to pay the full costs of water and sanitation, including for economic and environmental externalities, as required by EU Water Framework Directive, provided that there is a system of social support, so that the poor can still fulfill their basic needs. This is exemplified by HRW-countries in Europe: In France and the United Kingdom water services are privatized to a large extent (i.e., goal 1), but there are regulations to ensure that the poor unable to pay their bill are not easily disconnected. In Belgium, under HRW the poor either receive free basic water or social support to pay their water bill.

\section{Conclusions}

Within certain budgetary constraints all legitimate governments aim at providing and improving water services. Implicitly this acknowledges HRW, as is corroborated by the fact that HRW-countries neither displayed significantly better governance nor provided better services (Section 6). Thus, more research is needed on how HRW is best implemented.

For instance (Section 5), based on 120+ HRW-related cases from 55+ countries, one may conclude that individuals could successfully challenge violations of HRW within the ambit of first generation HR, such as discrimination, water pollution or depletion. However, with respect to affordability, case-law confirmed that the progressive realization of HRW is meant, without giving individuals a specific right for the delivery of water services with certain characteristics as to quantum, quality, or costs (for HRW-countries: Israel \#56, South Africa \#88). Individuals dependent on water holes from which also wild animals drink could only wait for progress (Canada \#23). However, the situation may change, as since 2013 individuals may complain to the CESCR treaty body about the violation of core HRW obligations, as defined by General Comment 15 (Section 4). In Europe, such litigation under ESC proving systematic inattention of authorities to pressing social needs was successful (France \#34).

In view of this case law it might be premature to conclude from poor performance indicators (Section 6), that HRW-countries would rather not respect HRW. For although, compared with non-HRW-countries, water-governance in HRW-countries was stochastically worse in several aspects, in countries with a history of deficient water provision the acceptance of HRW may have had improved the situation. Many HRW-countries for various reasons (e.g., geography, political instability) suffered from problematic water provision and acceptance of HRW indicates awareness of society for this problem. Clearly awareness alone cannot improve the situation.

The paper analyzed also different policies to realize HRW by means of reasonably endowed funding programs targeting the poor (Section 7). Under an HRW perspective, governments may follow two approaches: Low-income countries may focus on the successful support of the poor, using public means also for capacity building to enhance water-governance and to ensure that beneficiaries invest in infrastructure, which they can maintain. In high-income countries that support the poor from other budget items, governments may focus on the economic use of public money and let the poor pay the full costs, including for externalities. However, in low-income countries, where private water-companies implemented this policy, it resulted in conflicts. Both approaches may be enhanced by pro-women policies, civil society organization involvement, and participatory planning. 
This paper aims to contribute positively to an international development towards a progressive and effective HRW by elaborating some correlations with relevance for national and international policy makers. The consideration of feasible policy goals in awareness of previously failing or at least problematic policy goals is crucial and shall thus be emphasized in this conclusion.

\section{Acknowledgements}

The research for this paper has been complemented with results of the collaborative project "SARASWATI: Supporting consolidation, replication and up-scaling of sustainable wastewater treatment and reuse technologies for India" and "SAPH PANI: Enhancement of natural water systems and treatment methods for safe and sustainable water supply in India". Co-funding of SARASWATI and SAPH PANI from the European Commission within the Seventh Framework Programme (grant agreement numbers 308672 and 282911) is gratefully acknowledged. The authors appreciate insightful comments by two anonymous reviewers.

\section{Author Contributions}

All authors are responsible for the conception of the paper, author 1 for cross country comparison (Section 6), author 2 conducted the surveys (Section 7), authors 3 and 5 provided information about the domestic (Section 5,9) respectively international (Sections 4, 5, 9) situations and authors 1 and 4 did the policy modeling (Section 7).

\section{Conflicts of Interest}

The authors declare no conflict of interest.

\section{Abbreviations}

ACHPR: African Charter on Human and Peoples' Rights;

ACHR: American Convention on Human Rights;

ACnHPR: African Commission on Human and Peoples' Rights under ACHPR;

ACtHPR: African Court on Human and Peoples' Rights under ACHPR;

ADRDM: American Declaration of the Rights and Duties of Man;

CAT: UNO Convention against Torture and Other Cruel Inhuman or Degrading Treatment or Punishment; CCPR: UNO Covenant on Civil and Political Rights;

CEDAW: UNO Convention on the Elimination of All Forms of Discrimination against Women;

CERD: UNO Convention on the Elimination of All Forms of Racial Discrimination;

CESCR: UNO Covenant on Economic Social and Cultural Rights;

CMW: UNO Convention on the Protection of the Rights of All Migrant Workers and Members of their Families;

CRC: UNO Convention on the Rights of the Child;

CRPD: UNO Convention on the Right of Persons with Disabilities;

ECE: UNO Economic Commission for Europe;

ECeSR: European Committee of Social Rights under ESC;

ECHR: European Convention for the Protection of Human Rights and Fundamental Freedoms; 
ECtHR: European Court of Human Rights under ECHR;

ECtJ: European Court of Justice under TFEU;

ESC: European Social Charta;

EU: European Union;

EUR: Euro $(€)$;

FAO: Food and Agriculture Organization;

HR: human right(s);

HRCe: Human Rights Committee under CCPR;

HRW: human right to water;

HRW-country: accepts HRW in domestic law or policy;

IACnHR: Inter-American Commission on Human Rights under ADRDM;

IACtHR: Inter-American Court of Human Rights under ACHR;

ICSID: Convention on the Settlement of Investment Disputes between States and Nationals of other States;

ILO: International Labor Organization;

INR: Indian Rupees;

LPCD: liters per capita and day;

OECD: Organization for Economic Co-operation and Development;

SCt X: Supreme Court of country X;

TFEU: Treaty about the Functioning of the European Union;

UNO: United Nations Organization;

USA: United States of America;

USD: USA dollars (\$);

WHO: World Health Organization;

WTP: willingness to pay. 


\section{Appendix: Tables of Country Data and Case-Law}

Table A1. Sample data for eleven countries.

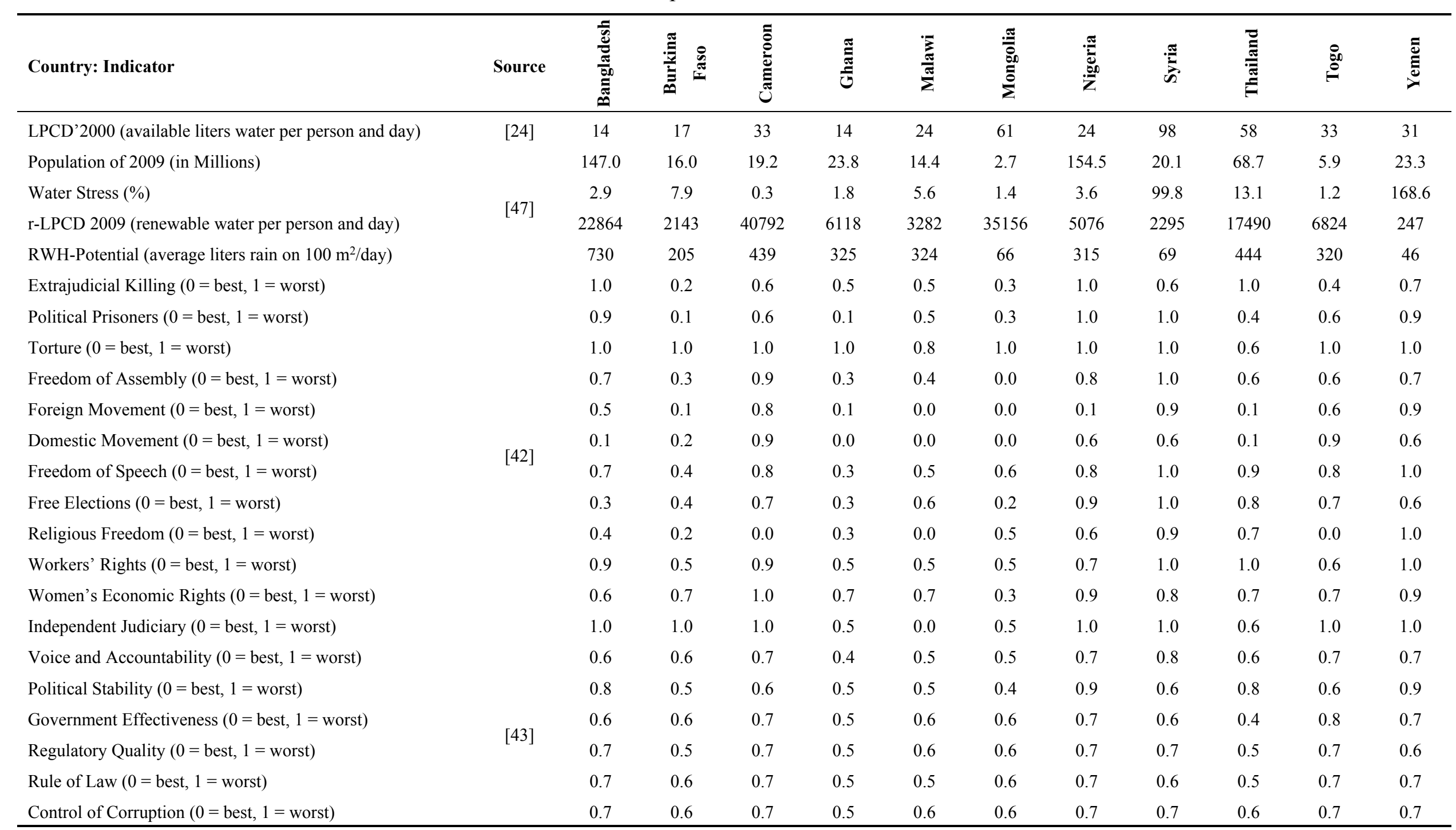


Table A1. Cont.

\begin{tabular}{|c|c|c|c|c|c|c|c|c|c|c|c|c|}
\hline Country: Indicator & Source & 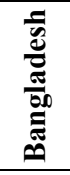 & 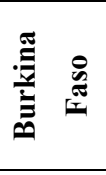 & Ũ & $\begin{array}{l}\stackrel{\widetilde{E}}{\mathbb{E}} \\
\tilde{U}\end{array}$ & 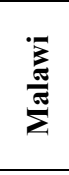 & 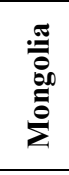 & 离 & 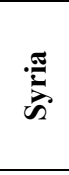 & 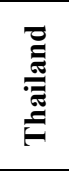 & $\stackrel{8}{\stackrel{8}{\theta}}$ & : \\
\hline Demographic Pressures $(0=$ best, $10=$ worst $)$ & \multirow{12}{*}[46]{} & 8.1 & 9.4 & 8.3 & 6.7 & 8.9 & 5.5 & 8.5 & 5.6 & 7.9 & 8.2 & 9.3 \\
\hline Refugees and IDPs $(0=$ best, $10=$ worst $)$ & & 7.3 & 7.4 & 7.3 & 5.5 & 6.5 & 2.2 & 6.6 & 9.5 & 6.4 & 7.1 & 9.2 \\
\hline Group Grievance $(0=$ best, $10=$ worst $)$ & & 8.6 & 5.3 & 7.8 & 4.9 & 5.7 & 3.7 & 9.8 & 9.3 & 8.1 & 4.8 & 9.0 \\
\hline Human Flight $(0=$ best, $10=$ worst $)$ & & 7.5 & 6.3 & 7.2 & 7.3 & 8.1 & 2.5 & 7.3 & 6.2 & 3.5 & 6.8 & 7.4 \\
\hline Uneven Development $(0=$ best, $10=$ worst $)$ & & 7.8 & 8.4 & 7.8 & 6.5 & 8.0 & 6.3 & 9.2 & 7.2 & 6.4 & 7.6 & 8.1 \\
\hline Poverty and Economic Decline $(0=$ best, $10=$ worst $)$ & & 7.3 & 7.7 & 6.1 & 6.1 & 8.4 & 4.7 & 7.5 & 6.4 & 3.5 & 7.4 & 9.2 \\
\hline Legitimacy of the State $(0=$ best, $10=$ worst $)$ & & 8.3 & 7.7 & 8.5 & 5.1 & 7.5 & 5.3 & 8.8 & 9.6 & 6.2 & 8.3 & 9.3 \\
\hline Deteriorating Public Services $(0=$ best, $10=$ worst $)$ & & 8.0 & 8.7 & 8.4 & 7.6 & 8.2 & 5.7 & 9.3 & 7.0 & 4.6 & 8.3 & 8.7 \\
\hline Human Rights Total $(0=$ best, $10=$ worst $)$ & & 7.3 & 6.8 & 8.1 & 4.7 & 6.8 & 5.4 & 8.6 & 9.5 & 7.3 & 7.8 & 8.7 \\
\hline Faulty Security Apparatus $(0=$ best, $10=$ worst $)$ & & 7.7 & 7.2 & 8.0 & 3.8 & 5.0 & 4.4 & 9.5 & 9.8 & 7.8 & 7.4 & 9.8 \\
\hline Factionalized Elites $(0=$ best, $10=$ worst $)$ & & 8.9 & 7.3 & 9.2 & 5.0 & 7.6 & 5.5 & 9.4 & 9.2 & 8.8 & 7.5 & 9.5 \\
\hline External Intervention $(0=$ best, $10=$ worst $)$ & & 5.8 & 8.0 & 6.8 & 6.0 & 8.4 & 6.5 & 6.3 & 8.1 & 4.6 & 6.5 & 8.7 \\
\hline Maximum of "No Improved water": two sources below & \multirow[t]{2}{*}{-} & 17 & 23 & 31 & 22 & 25 & 28 & 51 & 12 & 6 & 41 & 45 \\
\hline No Improved Water (\%) & & 2 & 23 & 31 & 22 & 25 & 28 & 51 & 12 & 6 & 39 & 41 \\
\hline No Piped Water (\%) & \multirow{4}{*}{ [9] } & 32 & 89 & 80 & 84 & 94 & 78 & 83 & 13 & 9 & 82 & 51 \\
\hline If water fetching: $\%$, where women fetch & & 89 & 85 & 46 & 64 & 87 & 32 & 47 & 22 & 61 & 58 & 68 \\
\hline If water fetching: $\%$, where men fetch & & 5 & 8 & 26 & 17 & 6 & 49 & 35 & 74 & 32 & 11 & 11 \\
\hline If water fetching: $\%$, where children fetch & & 6 & 6 & 28 & 16 & 7 & 19 & 19 & 2 & 5 & 17 & 16 \\
\hline No Electricity (\%) & \multirow{4}{*}[50]{} & 40 & 87 & 46 & 28 & 93 & 12 & 52 & 7 & 1 & 74 & 60 \\
\hline No Improved Water (\%) & & 17 & 20 & 26 & 14 & 16 & 15 & 39 & 10 & 4 & 41 & 45 \\
\hline No Improved Sanitation (\%) & & 45 & 82 & 52 & 87 & 47 & 47 & 69 & 5 & 7 & 89 & 47 \\
\hline No Improved Cooking (\%) & & 91 & 93 & 75 & 83 & 99 & 77 & 75 & 0.3 & 34 & 98 & 36 \\
\hline
\end{tabular}


Table A2. International and domestic case-law related to affordability, disconnections, depletion, pollution, encroachment and discrimination.

\begin{tabular}{|c|c|c|c|}
\hline No & Country & Treaty & Explanation \\
\hline 1. & Angola & ACHPR & Illegal immigrants from Gambia were held in detention centers with inadequate sanitation; degrading treatment [201]. \\
\hline 2. & Argentina & ICSID & $\begin{array}{l}\text { Argentina prohibited tariff-increases resulting in the termination of the concession contract for water and sanitation services for Buenos Aires. While the treaty-body } \\
\text { acknowledged that HRW could be at stake, HRW could not justify unfair treatment of foreign investors [202]. }\end{array}$ \\
\hline 3. & Argentina & domestic & $\begin{array}{l}\text { Under the right to life the government was responsible to provide the indigenous Toba population, Chaco Province, with access to basic amenities, including water [203]. } \\
\text { Further, lower-level courts declared disconnections for lacking capacity to pay as unconstitutional [204]. }\end{array}$ \\
\hline 4. & Armenia & ECHR & A prisoner had access to water and toilet facilities only twice a day; degrading treatment [205]. \\
\hline 5. & Austria & CCPR & $\begin{array}{l}\text { Landowners complained about excessive water and sewerage connection charges (ca. 15,000 EUR, compared to 20,757 EUR annual median wage in } 2000 \text { [206]). It was } \\
\text { calculated on the basis of plot size rather than on household size, as in other communities. No discrimination, as also household-size would have resulted in high charges [207]. }\end{array}$ \\
\hline 6. & Bangladesh & domestic & $\begin{array}{l}\text { Referring to Indian case-law [208], HRW was derived from the right to life (Article } 32 \text { Constitution). The petitioner complained about the failure by the government to } \\
\text { enforce laws that would protect against water pollution by tanneries. }\end{array}$ \\
\hline 7. & Bangladesh & domestic & To prevent overexploitation of groundwater, SCt stopped plans by Nestle to bottle water for the USA Kandahar Air Force Base [209]. \\
\hline 8. & Bangladesh & domestic & By the right to life, the forced eviction of sex-workers from red-light-districts of Dhaka was unlawful [210]. \\
\hline 9. & Belgium & ECHR & $\begin{array}{l}\text { An asylum seeker from Afghanistan suffered from refoulement [211,212], as in line with the EU-Schengen-treaty he was sent back to the country of first entry to EU, } \\
\text { although authorities should have known of the situation there, forcing him to beg for water and food. }\end{array}$ \\
\hline 10. & Belgium & ECHR & Asylum seekers from Lebanon, confined to the transit zone of Brussels airport, had to beg for water and food; degrading treatment [213]. \\
\hline 11. & Belgium & ECHR & The refusal of authorities to hear an environmental organization in proceedings about enlarging a landfill violated access to a court [214]. \\
\hline 12. & Belgium & ECHR & $\begin{array}{l}\text { A holiday home was built without a planning permission. } 37 \text { years later, police discovered that it was built in a woodland area, where no building-permit could be obtained, } \\
\text { and a court ordered its demolition. This interference was proportional, as property rights should not always take precedence over environmental considerations [215]; } \\
c f . \# 100 \text {. }\end{array}$ \\
\hline 13. & Belgium & domestic & Constitutional Court (then Court of Arbitration) declared Flanders' free basic water regulations as constitutional [216]. \\
\hline 14. & Botswana & domestic & An indigenous San community was not permitted to use water from the only borehole in its vicinity. The highest court found a violation of the prohibition of torture [217]. \\
\hline 15. & Brazil & ADRDM & $\begin{array}{l}\text { The construction of a road and mining led to massive intrusions of foreigners into indigenous land. Amongst others the rights to life and family life were invoked and } \\
\text { the state was made responsible to protect the Yanomani-People's well-being [218]. }\end{array}$ \\
\hline 16. & Brazil & domestic & Consumer Protection Code prohibits water-disconnections in the case of non-payment for lack of means [219]. \\
\hline 17. & Bulgaria & CCPR & $\begin{array}{l}\text { Evictions from a hitherto tolerated informal Roma settlement would violate the protection of private homes; amongst the issues was the interruption of the water lines } \\
\text { by the municipality to chase the settlers away [220]. Another complaint against evictions was inadmissible, as the municipality had offered accommodation for rent } \\
\text { before it demolished } 32 \text { homes [221]. }\end{array}$ \\
\hline
\end{tabular}


Table A2. Cont.

\begin{tabular}{|c|c|c|c|}
\hline No & Country & Treaty & Explanation \\
\hline 18. & Bulgaria & ECHR & $\begin{array}{l}\text { Enforcing eviction orders against Roma families from hitherto tolerated irregular settlements would violate private life [222]. Although the orders were lawful and } \\
\text { pursued a legitimate goal, namely to remedy the untenable sanitation situation (no water in the homes, open defecation), they were not proportional. Instead, } \\
\text { authorities should have assisted the families in finding alternative accommodations. }\end{array}$ \\
\hline 19. & Bulgaria & ECHR & $\begin{array}{l}\text { Harm to health from water pollution due to the reclamation of a pond of a former copper mine was doubted, as the pond was several kilometers away; no private } \\
\text { life violation [223]. }\end{array}$ \\
\hline 20. & Bulgaria & ECHR & The applicant could not prove that negligent storm water management caused the flooding of her house; no violation [224]. \\
\hline 21. & Canada & CCPR & $\begin{array}{l}\text { The cultural rights of a minority were violated [225], as ancestral land was expropriated for commercial exploitation (oil and gas industry, pulp mill). The loss of } \\
\text { their economic base resulted in a breakdown of social institutions (traditional systems of water and sanitary management), forced them to change their way of life, } \\
\text { and exposed them to diseases by lack of water and sanitary facilities. }\end{array}$ \\
\hline 22. & Canada & domestic & $\begin{array}{l}\text { Development projects affecting indigenous communities require their consultation, as in a development project, where groundwater from the Chemainus Aquifer } \\
\text { underneath ancestral land of the Halalt People should be extracted [226]. }\end{array}$ \\
\hline 23. & Canada & domestic & $\begin{array}{l}95 \% \text { of houses of Pikangikum in Ontario, Canada, an indigenous community with about two thousand people, have no piped water. Residents fetch drinking water } \\
\text { from a lake that is contaminated with sewage [227]. Lawsuits were dismissed, as petitioners would be uncooperative [228]; there are worries about racial } \\
\text { discrimination [229]. }\end{array}$ \\
\hline 24. & Chile & domestic & $\begin{array}{l}\text { Referring to the right to life, the Pascua Lama gold-mining project in the Atacama region was stopped as long as certain works to protect and manage the water } \\
\text { resources of the Huasco river-basin were not completed [230]. }\end{array}$ \\
\hline 25. & Colombia & domestic & $\begin{array}{l}\text { Disconnections of the poor for non-payment are only legitimate, if they steal water [231]. Thus, water company had to reconnect a sick woman, who could not afford to } \\
\text { pay her water bill [232]. }\end{array}$ \\
\hline 26. & Costa Rica & domestic & $\begin{array}{l}\text { Under the right to life authorities were responsible to prevent water pollution from a domestic waste dump [233]. "Access to safe drinking water constitutes an } \\
\text { inalienable HR that may be enforced in national courts" [234]. }\end{array}$ \\
\hline 27. & Costa Rica & domestic & Under the right to a healthy environment development projects impacting aquifers are subject to an environmental impact assessment [235]. \\
\hline 28. & $\begin{array}{l}\text { Dominican } \\
\text { Republic }\end{array}$ & CCPR & A prisoner was denied water and food for one day, violating Article 10 [236]. \\
\hline 29. & Ecuador & ACHR & $\begin{array}{l}\text { Destruction of ancestral land by pollution violated the property rights of an indigenous community of the Amazon basin, as the government permitted oil } \\
\text { explorations, backed by military force, and without consulting the community [237]. Oil exploration caused large-scale contamination of water sources, resulting in } \\
\text { a public health emergency [238]. }\end{array}$ \\
\hline 30. & France & ECHR & $\begin{array}{l}\text { A politician was convicted for libel of a civil servant, who allegedly misinformed the public about dangers from radioactive fallout following the Chernobyl } \\
\text { disaster. Due to the importance of this debate, the conviction was unreasonable; free speech violation [239]. }\end{array}$ \\
\hline 31. & France & ECHR & $\begin{array}{l}\text { The criminal conviction of environmental activists, who destroyed genetically modified crops, did not violate their right to life or health (private life), as their action } \\
\text { was not justified by the precautionary principle, considering that their homes and farms were far away [240]. }\end{array}$ \\
\hline
\end{tabular}


Table A2. Cont.

\begin{tabular}{|c|c|c|c|}
\hline No & Country & Treaty & Explanation \\
\hline 32. & France & ECHR & $\begin{array}{l}\text { Owners of an island sold most of it to the state and were assured that on the remainder they could build houses. But authorities invoked environmental protection and } \\
\text { prohibited constructions. This refusal to honor contractual obligations violated the right to property [241]. }\end{array}$ \\
\hline 33. & France & ECHR & $\begin{array}{l}\text { Private life violation was found, if eviction orders against Roma families from hitherto tolerated irregular settlements would be enforced [242], the facts being similar to } \\
\text { a previous case against Bulgaria. }\end{array}$ \\
\hline 34. & France & $\mathrm{ESC}$ & $\begin{array}{l}\text { ECeSR confirmed that the right to housing (Article 31) guarantees everyone "a dwelling which is safe from a sanitary and health point of view, that is, possesses all } \\
\text { basic amenities, such as water, heating, waste disposal, sanitation facilities and electricity; is structurally secure; not overcrowded; and with secure tenure supported by } \\
\text { the law" [243]. France fell short in the progressive realization, as no systematic scheme to address the problem of substandard housing was implemented, affecting more } \\
\text { than a million persons. }\end{array}$ \\
\hline 35. & France & domestic & Communities may not invoke HRW to prohibit disconnections [244]. \\
\hline 36. & Germany & ECHR & $\begin{array}{l}\text { Greenpeace complained about a busy road and requested that the government should oblige car manufacturers to build environmentally friendly cars. The application } \\
\text { was manifestly ill-founded, as under ECHR there is no explicit right to a healthy environment [245]. }\end{array}$ \\
\hline 37. & Greece & CCPR & $\begin{array}{l}\text { The destruction of homes in the Roma settlement near Patras with an untenable sanitary condition violated amongst others the protection of private homes [246]. The } \\
\text { complaint about degrading treatment was admissible, but not decided. }\end{array}$ \\
\hline 38. & Greece & ECHR & $\begin{array}{l}\text { An asylum seeker from Afghanistan was left in a vulnerable situation without any support [211]; inhumane treatment: He lived for several weeks in „,a state of the most } \\
\text { extreme poverty, unable to cater for his most basic needs: food, hygiene and a place to live“. However, other than under such special circumstances, ECHR would not } \\
\text { imply a right to food, water or a shelter as such. }\end{array}$ \\
\hline 39. & Greece & ESC & $\begin{array}{l}\text { Lacking information about drinking water pollution violated HRW under the aspect of the right to health [247]: Pollution of Asopos River with heavy metal from } \\
\text { tanneries finally compromised drinking water quality in the Oinofyta region, but the government failed to take precautionary measures and only belatedly informed the } \\
\text { population that municipal water was unfit for consumption. }\end{array}$ \\
\hline 40. & Grenada & $\mathrm{ACHR}$ & A death-row inmate was provided with a bucket as a toilet, emptied once a day; degrading treatment [248]. \\
\hline 41. & Iceland & CCPR & $\begin{array}{l}\text { This case affects water management indirectly, as it criticized an allocation of quota for the commercial exploitation of a common national property, fish stocks: There } \\
\text { was a discrimination, as fishers active in a reference period received free quotas, and all others had to purchase quotas from them [249]. }\end{array}$ \\
\hline 42. & India & domestic & In a landmark case about bonded laborers without access to clean water [250], under the right to life everyone is guaranteed „to live with human dignity“. \\
\hline 43. & India & domestic & $\begin{array}{l}\text { In view of the overexploitation of Haryana and Jamuna rivers for irrigation, which let Delhi suffer from water shortage [251], sufficient water was reserved for Delhi, as } \\
\text { drinking "cannot be made subservient to any other use of water, like irrigation". }\end{array}$ \\
\hline 44. & India & domestic & $\begin{array}{l}\text { Groundwater extraction by Coca Cola Company in Plachimada, Kerala, was restricted [252]; SCt cited this as exemplary [253]. Subsequent proceedings permitted the } \\
\text { extraction of } 500 \mathrm{~m}^{3} \text { per day, which practically reversed the initial order; the dispute is pending at SCt India. }\end{array}$ \\
\hline 45. & India & domestic & $\begin{array}{l}\text { To fulfill its water needs, Tamil Nadu state leases and operates Mullaperiyar Dam in Kerala, constructed in } 1895 \text {. Kerala state was concerned about the earthquake-safety } \\
\text { and enacted a state-law to limit the reservoir level. In view of the nature of the subject matter of this legislation (inter-state), this law was declared as unconstitutional [254]. }\end{array}$ \\
\hline
\end{tabular}


Table A2. Cont.

\begin{tabular}{|c|c|c|c|}
\hline No & Country & Treaty & Explanation \\
\hline 46. & India & domestic & $\begin{array}{l}\text { During the Bhopal disaster (Madhya Pradesh) of } 2 \text { December 1984, leaking methyl-isocynate killed } 3787 \text { people. Under the right to life, Union Carbide Cooperation } \\
\text { paid } 470 \text { million USD in damages [255]. The Bhopal Gas Leak Disaster Processing of Claims Act of } 1985 \text { was constitutional [256]. }\end{array}$ \\
\hline 47. & India & domestic & The precautionary and polluter-pays principles apply also to private enterprises, referring to a gas-leak incident in Delhi [257]. \\
\hline 48. & India & domestic & $\begin{array}{l}\text { Concerning the discharge of toxic effluents from tanneries into Palar River, polluting drinking water and farmland, the government had to constitute an authority to } \\
\text { resolve this issue (damages, cleanup) in accordance with the precautionary and polluter pays principles [258]. }\end{array}$ \\
\hline 49. & India & domestic & $\begin{array}{l}\text { In view of the pollution of ecologically fragile coastal areas by prawn farming, the aquaculture industries had to be destroyed and the government was ordered to establish a } \\
\text { regulatory authority [259]. }\end{array}$ \\
\hline 50. & India & domestic & In order to restore a piece of open land, SCt ordered the demolition of a pilgrim hostel built with the consent of the municipality [260]. \\
\hline 51. & India & domestic & Forced evictions of slum dwellers in Mumbai, Maharashtra, would be unlawful, unless they were offered alternative accommodation [261]. \\
\hline 52. & India & domestic & $\begin{array}{l}\text { When an indigenous community has been relocated without compensation to make place for the Pench National Park and its tiger reserve, SCt ordered that only certain } \\
\text { permit holders of that community may enter the park under stringent supervision, whereas initially the government permitted them unrestricted access for fishing to } \\
\text { secure their subsistence in traditional ways [262]. }\end{array}$ \\
\hline 53. & India & domestic & With respect to the provision of affordable access to water, HRW is an obligation to ensure progressive realization, only [263]. \\
\hline 54. & Indonesia & domestic & $\begin{array}{l}\text { Referring to international law, Constitutional Court confirmed Water Law (which enabled privatization) as constitutional, provided that it was applied so as to respect the } \\
\text { right to water [264]. }\end{array}$ \\
\hline 55. & Israel & domestic & $\begin{array}{l}\text { HRW follows from the right to human dignity and liberty (Section } 8 \text { Basic Law), subject to proportionality: It was unlawful to spray herbicide from the air to destroy } \\
\text { illegally planted crop on state land, as this would jeopardize the health of the encroachers [265]. But it was lawful for Water Authority to provide water access points to } \\
\text { legally recognized settlements, only [266]. }\end{array}$ \\
\hline 56. & Israel & domestic & The regulation of drinking water quality is left to the discretion of the government [267]. \\
\hline 57. & Italy & ECHR & $\begin{array}{l}\text { The Seveso disaster of } 10 \text { July } 1976 \text { exposed thousands of people to dioxin, polluting air, water and the soil. There was no legal mechanism by which authorities or } \\
\text { industry were obliged to inform the concerned population about health risks and emergency measures; private life violation [268]. Remarkably, such duty was not } \\
\text { derived from free speech (right of access to information, as suggested by the applicants). }\end{array}$ \\
\hline 58. & Italy & ECHR & $\begin{array}{l}\text { A waste treatment plant was operating since 1982, but only in } 2000 \text { an environmental impact assessment found excessive emissions; private life violation, as the } \\
\text { assessment was not conducted earlier and the operation of the plant was not suspended [269]. }\end{array}$ \\
\hline 59. & Italy & ECHR & In 2007 and 2008 municipal waste collection of Naples broke down, leaving unsanitary conditions; private life violation [270]. \\
\hline 60. & Italy & ECHR & $\begin{array}{l}\text { Developers obtained a planning permission from Bari municipality contrary to environmental regulations; courts ordered the demolition of the buildings and confiscation of } \\
\text { the land. However, also courts acknowledged that the applicants had made inevitable errors in interpreting the relevant regulations. The right to property was violated, as such } \\
\text { regulations lacked the "quality of a law" [271]. }\end{array}$ \\
\hline
\end{tabular}


Table A2. Cont.

\begin{tabular}{|c|c|c|c|}
\hline No & Country & Treaty & Explanation \\
\hline 61. & Italy & $\mathrm{ESC}$ & The poor housing situation of the Roma minority was a concern for several countries, amongst them Italy [272]. \\
\hline 62. & Jamaica & CCPR & Lack of adequate sanitation in a prison cell violated Article 10 [273]. \\
\hline 63. & Kenya & ACHPR & $\begin{array}{l}\text { The pastoral Endorois community of the Rift Valley was forcibly removed from ancestral grounds to make place for a game reserve and ruby mining [274]. Amongst } \\
\text { others this was incompatible with religious freedom, as the government blocked access to sacred places along Lake Bogoria, where they regularly conducted } \\
\text { ceremonies. Further (Article 21), the community had no longer access to the natural resources of that lake, including certain herbs for their cattle, and they did not } \\
\text { receive a fair share of the revenues from ruby mining. }\end{array}$ \\
\hline 64. & Kenya & domestic & Under HRW, following the demolition of an informal settlement the government had to provide reasonable accommodation [275]. \\
\hline 65. & Latvia & ECHR & $\begin{array}{l}\text { An environmentalist association was ordered to pay damages for criticism of a mayor for malpractice, jeopardizing sensitive coastline habitats. Such silencing of a } \\
\text { "watchdog" was not reasonable; violation of free speech [276]. }\end{array}$ \\
\hline 66. & Luxembourg & ECHR & $\begin{array}{l}\text { A complaint against violations of procedural rights in proceedings to delimit pollution from steelworks was inadmissible, as authorities took all necessary steps to } \\
\text { ensure compliance of business with the conditions of the operating licenses [277]. }\end{array}$ \\
\hline 67. & Luxembourg & TFEU & $\begin{array}{l}\text { ECtJ ordered Luxembourg to pay the EU Commission a fine of two million Euros, as despite previous judgments certain treatment plants still discharged } 50 \% \text { more } \\
\text { nitrogen than admissible by the Urban Wastewater Directive [278]. }\end{array}$ \\
\hline 68. & Malaysia & domestic & Disconnections due to defective metering were unlawful [279]. \\
\hline 69. & Mexico & domestic & Plans to redirect water from Yaqui River to Hermosillo City in the Sonora River Basin were stopped; it would have taken water away from the indigenous population [280]. \\
\hline 70. & Nepal & domestic & Under the right to life the government was responsible to take measures against drinking water pollution caused by mining industry [281]. \\
\hline 71. & Nepal & domestic & $\begin{array}{l}\text { The practice of chaupadi was abolished, as it discriminated against women [282]. It forced menstruating women and girls to sleep in isolation from the rest of the } \\
\text { family in order to protect water wells. }\end{array}$ \\
\hline 72. & Netherlands & domestic & Disconnecting water for non-payment of 2000 EUR water-bill was compatible with HRW [283]. \\
\hline 73. & Nigeria & ACHPR & $\begin{array}{l}\text { Oil development resulted in massive pollution (right to health) and government-sponsored attacks on the Ogoni communities; for future oil developments } \\
\text { environmental impact assessments are needed [105]. }\end{array}$ \\
\hline 74. & Pakistan & domestic & "The right to have water free from pollution and contamination is a right to life itself." [284]; hence mining workers were entitled to receive clean water. \\
\hline 75. & Panama & ACHR & An illegal immigrant from Ecuador was detained without access to water; degrading treatment [285]. \\
\hline 76. & Paraguay & ACHR & $\begin{array}{l}\text { Indigenous communities were pressured to relocate, depriving them of their traditional means of livelihood [286-288]. They were left stranded along roads with } \\
\text { insufficient access to e.g., clean water. Despite emergency aid, the morbidity of children and elderly persons was high. This violated the right to life; as a remedy the } \\
\text { government should restitute ancestral lands. In the meantime it should provide the communities with basic amenities. }\end{array}$ \\
\hline
\end{tabular}


Table A2. Cont.

\begin{tabular}{|c|c|c|c|}
\hline No & Country & Treaty & Explanation \\
\hline 77. & Peru & CCPR & $\begin{array}{l}\text { The government diverted water from the Andes for the drinking water supply of Tacna City on the Pacific coast [289]. Invoking HRW, planners considered that } \\
\text { extraction of water was of higher priority than its traditional use by the indigenous Aymara community for raising alpaca and llama in the Andes. Consequently, their } \\
\text { pastures dried out and the community lost their livestock. This was a violation of the cultural rights of minority communities, as the development project endangered } \\
\text { their very survival. As minimal requirement, the affected communities should have been allowed to participate in the decision-making processes. }\end{array}$ \\
\hline 78. & Philippines & domestic & Under the right to health, timber licenses were annulled, as deforestation had adverse impact on natural water-balance [290]. \\
\hline 79. & Portugal & ECHR & $\begin{array}{l}\text { Since } 1884 \text { the applicant company has cultivated land at the Algarve coast under a concession contract. In order to protect coastal and river ecosystems, the } \\
\text { government planned to expropriate land, withdraw concessions, and order restrictions on working the land. The ensuing proceedings lasted for } 13 \text { years, which was } \\
\text { excessive (Article 6). The legal uncertainty violated the right to property [291]. }\end{array}$ \\
\hline 80. & Portugal & domestic & A disconnection to exert pressure for the payment of another debt was unlawful [292]. \\
\hline 81. & Rumania & ECHR & $\begin{array}{l}\text { Sodium cyanide from a gold mine near Baia Mare leaked into rivers and travelled } 800 \mathrm{~km} \text {. The government failed to assess risks correctly and keep the public } \\
\text { informed; private life violation [293]. }\end{array}$ \\
\hline 82. & Rumania & ECHR & $\begin{array}{l}\text { In view of conflicts with other neighbors, the water provider denied the applicants to reopen their piped water connection and it ignored court rulings ordering this. } \\
\text { The government was responsible to enforce the court rulings; Article } 6 \text { violated [294]. }\end{array}$ \\
\hline 83. & Rumania & ECHR & Prisoners were detained for several years under appalling sanitary conditions; degrading treatment $[295,296]$. \\
\hline 84. & Russia & ECHR & $\begin{array}{l}\text { The sanitation situation of prison cells was inadequate, as the toilets were located close to the dining tables; degrading treatment [297]. In another case a prisoner was } \\
\text { held for one day in a cell without food, drink, or unrestricted access to a toilet; degrading treatment [298]. }\end{array}$ \\
\hline 85. & Russia & ECHR & $\begin{array}{l}\text { Authorities acknowledged the heavy pollution from a Soviet-era steel plant and established a buffer zone around it. However, those living in the buffer zone were not } \\
\text { supported to relocate; private life violation [299]. }\end{array}$ \\
\hline 86. & Slovakia & CERD & $\begin{array}{l}\text { The Roma minority of Dobšiná was living in informal settlements without access to water and as a remedy the municipality planned a low-cost housing program. } \\
\text { However, bowing to protests by the majority, local authorities stopped the project; racial discrimination [300]. }\end{array}$ \\
\hline 87. & Slovenia & domestic & A disconnection because of disputes with neighbors was unlawful [301]. \\
\hline 88. & $\begin{array}{l}\text { South } \\
\text { Africa }\end{array}$ & domestic & $\begin{array}{l}\text { Petitioners from a slum in Soweto could not claim to receive any specific amount of basic free water [302]. Also metering was not unconstitutional, if it aimed at } \\
\text { ensuring rational use of water and economic viability of water provision. As HRW is a state obligation for progressive realization, water provision needs to remain } \\
\text { economically sustainable. It is up to the government to define, what amount of basic water is sufficient. As the provision of free basic water has increased, the } \\
\text { progressive realization of HRW was established. }\end{array}$ \\
\hline 89. & $\begin{array}{l}\text { South } \\
\text { Africa }\end{array}$ & domestic & $\begin{array}{l}\text { Following the planned eviction of } 20,000 \text { slum dwellers, government was responsible to provide adequate alternative accommodation. Thereby, under the right to an } \\
\text { adequate standard of living homes "must be equipped with basic services, including tarred roads, electricity (by prepaid meter), fresh water and reasonable provision } \\
\text { for toilet facilities" [303]. }\end{array}$ \\
\hline
\end{tabular}


Table A2. Cont.

\begin{tabular}{|c|c|c|c|}
\hline No & Country & Treaty & Explanation \\
\hline 90. & Spain & CCPR & A prisoner was denied water for five days in violation of Article 10 [304]. \\
\hline 91. & Spain & ECHR & $\begin{array}{l}\text { A malfunctioning wastewater treatment plant for tanneries caused health problems for a family in the neighborhood, who moved away. There was a private life } \\
\text { violation, as authorities caused a prolongation of the family's suffering by appealing against judicial decisions that would have resolved the matter more speedily [305]. }\end{array}$ \\
\hline 92. & Spain & ECHR & The bail for a captain responsible for large scale environmental pollution was not excessive; no violation of Article 5, liberty [306]. \\
\hline 93. & $\begin{array}{l}\text { Sudan } \\
\text { (North) }\end{array}$ & ACHPR & $\begin{array}{l}\text { Denial of access to water was a factor for the humanitarian crisis in Darfur [307], where the Janjaweed militia poisoned wells of indigenous black African tribes to } \\
\text { chase them away; violation of the right to health, as the militia acted with tacit government approval [308]. }\end{array}$ \\
\hline 94. & Suriname & ACHR & $\begin{array}{l}\text { The right to property of an indigenous population was violated, as the state issued licenses for logging and gold-mining without considering the interests of the local } \\
\text { population or sharing with them the benefits; for instance, mercury used in gold-mining poisoned drinking water [309]. However, concerns about water pollution from } \\
\text { gold-mining continued [310]. }\end{array}$ \\
\hline 95. & Sweden & ECHR & $\begin{array}{l}\text { Cyanide from a licensed dump percolated into groundwater, contaminating drinking water wells, but neighbors could not challenge at domestic courts the licensing; } \\
\text { violation of Article } 6 \text { [311]. Some authors consider that this case has established HRW for Europe [312], as it implied that water was a civil right of individuals, which } \\
\text { is a precondition for the application of Article } 6 .\end{array}$ \\
\hline 96. & Sweden & TFEU & ECtJ found a violation of the Urban Wastewater Directive, as nitrogen removal was insufficient for certain wastewater plants [313]. \\
\hline 97. & Tajikistan & CCPR & A prisoner was detained in a cell without water, violating Article 10 [314]. \\
\hline 98. & Tunisia & CAT & For the finding of violations it mattered that prison cells lacked water [315]. \\
\hline 99. & Turkey & ECHR & $\begin{array}{l}\text { A house built without a permit in the absolute protection zone for a drinking water basin was demolished. This violated property rights, as the house was purchased in } \\
\text { good faith from the previous owner and authorities were obliged to strike a fair balance between the interests of the applicant for compensation and those of society for } \\
\text { environmental protection [316]. }\end{array}$ \\
\hline 100. & Turkey & ECHR & $\begin{array}{l}\text { A piece of land that for generations belonged to the applicant's family was expropriated without compensation for nature-conservation purposes, whereby experts } \\
\text { declared it as part of a state forest; violation of the right to property [317]. }\end{array}$ \\
\hline 101. & Turkey & ECHR & $\begin{array}{l}\text { Administrative authorities issued a permit for the use of cyanide in gold mining and ignored that administrative courts had annulled this decision; the rights to private } \\
\text { life and fair trial were violated [318]. However, similar cases occurred later [319,320]. }\end{array}$ \\
\hline 102. & Turkey & ECHR & $\begin{array}{l}\text { A slum dweller near Istanbul lost several relatives, when gas from a nearby waste dump exploded. The right to life was violated, as authorities neglected this danger ([321] } \\
\text { for landfill gas production); they should have evacuated the slum [322]. }\end{array}$ \\
\hline 103. & Ukraine & ECHR & During several years of detention, a prisoner suffering from tuberculosis was held in an overcrowded cell and allowed to shower only once a week; degrading treatment [323]. \\
\hline
\end{tabular}


Table A2. Cont.

\begin{tabular}{|c|c|c|c|}
\hline No & Country & Treaty & Explanation \\
\hline 104. & Ukraine & ECHR & $\begin{array}{l}\text { Pollution from two state-owned factories made neighboring homes unsafe for residential use [324]. This was a private life violation, as the government could not } \\
\text { explain the failure within twelve years to either resettle the most affected families or to find another solution. }\end{array}$ \\
\hline 105. & $\begin{array}{l}\text { United } \\
\text { Kingdom }\end{array}$ & ECHR & $\begin{array}{l}\text { Domestic courts have to protect the right to free speech for environmental activists. Litigation of the Mc Donald's fast-food chain against a pamphlet asking for } \\
\text { more sustainable practices threatened it }[325,326] ; c f . \# 30, \# 65 \text {. }\end{array}$ \\
\hline 106. & $\begin{array}{l}\text { United } \\
\text { Kingdom }\end{array}$ & domestic & The Water Industry Act prohibits prepaid meters that cut off water supply automatically on non-payment [327]. \\
\hline 107. & USA & ADRDM & $\begin{array}{l}\text { Two members of the Shoshone People complained about gold-mining on their ancestral land in the Battle Mountain District of Nevada, thereby exploiting scarce } \\
\text { water resources; violation of procedural rights with respect to the right to property [328]. }\end{array}$ \\
\hline 108. & USA & domestic & Concerning \#107, an environmental impact assessment was ordered, in particular about the effect of gold-mining on groundwater [329]. \\
\hline 109. & USA & domestic & $\begin{array}{l}\text { Over fifty years a predominantly black community, Coal Run near Zanesville, Ohio, was denied a connection to a water supply system, whereas all neighboring } \\
\text { white communities were connected; racial discrimination [330]. }\end{array}$ \\
\hline 110. & Venezuela & domestic & Arbitrary disconnections violate the rights to health and adequate housing [331]. \\
\hline 111. & Zambia & CCPR & $\begin{array}{l}\text { A prisoner was denied water for three days; inhumane treatment in the meaning of Article } 10 \text { [332]. However, lacking access of detainees to water or sanitation } \\
\text { facilities alone would not amount to inhumane treatment in the meaning of Article } 7 \text { [333]. }\end{array}$ \\
\hline
\end{tabular}

Note: \# $\mathrm{x}$ is case $\mathrm{x}$ in Table A2. 
Table A3. List of HRW-countries and borderline cases.

\begin{tabular}{|c|c|c|}
\hline Country & Type & Explanation \\
\hline Algeria & LAW & The Water Law of 2005 recognizes HRW for basic needs. \\
\hline Angola & LAW & The Water Act of 2010 obliges the government to fulfill basic water needs. \\
\hline Argentina & CRT CON & $\begin{array}{l}\text { HRW follows from the right to life (\#3), Argentina invoked HRW as defense under ICSID ( } \# 2) \text {, and there is a right to a healthy environment (Article } 41 \text { Constitution of } \\
\text { 1853, amended 1994). However, initially there were beneficial effects of the privatization of water services [166], whereas "Argentinean law fails to ensure progressive } \\
\text { realization of the right to water or equitable distribution of the water supply" [334]. }\end{array}$ \\
\hline Bangladesh & CRT CON & The state has to secure "the provision of the basic necessities of life" (Article 15 Constitution of 1972). SCt derived HRW from the right to life (\#6). \\
\hline Belgium & $\mathrm{CON}$ & $\begin{array}{l}\text { The right to a live in human dignity includes decent housing (Article } 23 \text { Constitution of 1994). For implementation, municipalities in Flanders provide annually } 15 \mathrm{~m}^{3} \\
\text { per person free basic water (approved by courts: \#13), and in Wallonia the Social Funds subsidizes water for the poor [335]. }\end{array}$ \\
\hline Bolivia & $\mathrm{CON}$ & $\begin{array}{l}\text { The state guarantees "universal and fair access to the basic services of potable water" (Article } 20 \text { Constitution of 2009). There is a progressive water tariff system, with } \\
\text { low prices for the initial consumption. }\end{array}$ \\
\hline Botswana & CRT & HRW was derived from the prohibition of torture $(\# 14)$ \\
\hline Brazil & LAW & $\begin{array}{l}\text { The Law on Basic Sanitation of } 2007 \text { acknowledges HR to sanitation. Disconnections of water were unlawful (\#16). A participatory "conference mechanism" (user } \\
\text { participation at the municipal level, whose outcome is input at the state and national levels) ensures that all relevant water and sanitation decisions are informed about } \\
\text { user-preferences. }\end{array}$ \\
\hline Canada & NO HRW & Domestic case-law respects HRW-aspects (\#22). \\
\hline Chile & CRT CON & $\begin{array}{l}\text { HRW was derived from the right to life (\#24). Water for the rural poor is subsidized: Depending on household income, communities pay up to } 85 \% \text { of the monthly } \\
\text { water and sewerage bill for up to } 15 \mathrm{~m}^{3} \text { (Ley del Subsidio al Agua Potable y Saneamiento). The rights to health and to a clean environment (Article } 19 \text { Constitution of } \\
\text { 1980, amended 2010) are acknowledged. }\end{array}$ \\
\hline China, PR & $\mathrm{CON}$ & $\begin{array}{l}\text { The state promotes sanitation to protect health (Article } 21 \text { Constitution of 1981, amended 2004). The government developed policies to solve problems of water } \\
\text { shortages (Beijing: } 21 \text { st Century Capital Water Resources Sustainable Utilization Plan [336]; Northern China: South-North Water Transfer Project). China coauthored } \\
\text { also international HRW-initiatives, e.g., UN-Habitat-Resolution 20/5 of } 2005 \text { promoting access to basic services. }\end{array}$ \\
\hline Colombia & $\mathrm{CON}$ & $\begin{array}{l}\text { Provision of basic water needs is a basic objective of the state (Article } 366 \text { Constitution of 1991, amended 2005). Courts applied this and restricted disconnections (\#25). } \\
\text { Water tariff depends on the income, whereby the affluent subsidize the poor. }\end{array}$ \\
\hline Congo, DR & $\mathrm{CON}$ & HRW is mentioned as part of the right to housing (Article 48 Constitution of 2006). \\
\hline Costa Rica & CRT CON & HRW was derived from the right to life (\#26) and the right to a healthy environment (Article 50 Constitution; \#27). \\
\hline $\begin{array}{l}\text { Dominican } \\
\text { Republic }\end{array}$ & $\mathrm{CON}$ & Provision of water services is part of the obligation of social assistance to the poor ( $§ 17$ Article 8 Constitution of 2002). \\
\hline Ecuador & $\mathrm{CON}$ & HRW is part of the right to a dignified life ( $§ 2$ Article 67 Constitution of 2008). \\
\hline Eritrea & $\mathrm{CON}$ & The government is obliged to sustainable water management (Article 8 Constitution of 1997). \\
\hline Ethiopia & $\mathrm{CON}$ & HRW is guaranteed conditional on the availability of resources (Article 90 Constitution of 1998). \\
\hline
\end{tabular}


Table A3. Cont.

\begin{tabular}{|c|c|c|}
\hline Country & Type & Explanation \\
\hline France & LAW & $\begin{array}{l}\text { The Water and Aquatic Environment Law of } 2006 \text { stipulates the right to access drinking water under conditions economically acceptable by all. In order to ensure that } \\
\text { poor remain connected to piped water, social services (Fonds de Solidarite Logement) are alerted about non-payment (unless users oppose), but municipalities may not } \\
\text { prohibit disconnections \#35. }\end{array}$ \\
\hline Gambia & $\mathrm{CON}$ & The state promotes HRW (Article 216 Constitution of 1996, amended 2001). \\
\hline Ghana & $\mathrm{CON}$ & $\begin{array}{l}\text { The state promotes access to public services under the directive principles of state policy (Article } 35 \text { Constitution of 1992). Improving access to water and sanitation } \\
\text { facilities may have reduced assassinations of women [337]. }\end{array}$ \\
\hline Guatemala & $\mathrm{CON}$ & Amongst general obligations to protect public health, the state is obliged to ensure drinking water safety (Article 96 Constitution of 1985). \\
\hline Honduras & POL & The legal implementation of the right to food is under discussion and a government decree (38/2011 of 25.04.2011) addresses support for the poor. \\
\hline Hungary & $\mathrm{CON}$ & The right to health is acknowledged and mentions HRW ( $\$ 2$ Article 20 Constitution of 2011). \\
\hline India & CRT & Section 5.3 \\
\hline Indonesia & $\mathrm{CON}$ & $\begin{array}{l}\text { Exploitation of water and other natural resources is for "the maximal benefit of people" ( } \$ 3 \text { Article } 33 \text { Constitution of 1945, amended 2002); the Water Resources Law } \\
\text { guarantees access to water. }\end{array}$ \\
\hline Iran & $\mathrm{CON}$ & The state recognizes the provision of basic necessities as economic criterion (Article 43 Constitution of 1979). \\
\hline Israel & CRT & $\begin{array}{l}\text { HRW was derived and applied in the context of water-related conflicts between the government and Bedouins of the Negev Desert (\#55). These conflicts, and also the } \\
\text { destruction of water infrastructure in Palestine by Israel, have been concerns for the CESCR treaty-body [338]. }\end{array}$ \\
\hline Kazakhstan & LAW & The Water Code of 2003 gives priority to basic access to drinking water. \\
\hline Kenya & $\mathrm{CON}$ & The state guarantees "clean and safe water in adequate quantities" ( $§ 1 \mathrm{~d}$ Article 43 Constitution of 2010); courts applied HRW (\#64). \\
\hline Madagascar & LAW & The Water Law obliges public services to provide minimum needs of potable water. \\
\hline Maldives & $\mathrm{CON}$ & The state guarantees the progressive realization of HRW (Article 23a Constitution of 2008). \\
\hline Mauritania & $\mathrm{CON}$ & The state recognizes HRW (Article 57 Constitution of 1991). \\
\hline Mexico & NO HRW & Domestic courts protected access to water for indigenous populations (\#69). \\
\hline Morocco & LAW & The Water Law of 1995 gives emergency provision of water priority. \\
\hline Mozambique & LAW & The Water Act gives priority to water for human consumption. \\
\hline Nepal & $\begin{array}{l}\text { CRT } \\
\text { CON }\end{array}$ & $\begin{array}{l}\text { HRW follows from the right to life (\#70). Further, the right to "food sovereignty" ( } § 3 \text { Article } 18 \text { Interim Constitution of 2007) includes HRW; Water Resources Act of } \\
1992 \text { gives drinking-water priority over all other water uses. }\end{array}$ \\
\hline Netherlands & POL & In 2008 the government informed the UNO-HR-Council that it would acknowledge HRW. Water privatization was prohibited in 2004. \\
\hline New Zealand & NO HRW & $\begin{array}{l}\text { There are HRW aspects in Local Government Act: Municipalities entering a public private partnership (e.g., privatization of the water sector) need to monitor the } \\
\text { impact on the well-being of the community and control pricing [23]. }\end{array}$ \\
\hline Nicaragua & $\mathrm{CON}$ & The state promotes HRW (Article 47 Constitution of 1987, amended 2010) and obliges the government to provide basic facilities (Article 105). \\
\hline Niger & $\mathrm{CON}$ & HRW is mentioned under the right to life and health (Article 12 Constitution of 2010). \\
\hline
\end{tabular}


Table A3. Cont.

\begin{tabular}{|c|c|c|}
\hline Country & Type & Explanation \\
\hline Pakistan & CRT & HRW was derived from the right to life (\#74). Further, the state promises support for those unable to earn their livelihood (Article 38 Constitution of 1973, amended 2007). \\
\hline Panama & $\mathrm{CON}$ & $\begin{array}{l}\text { HRW is mentioned under right to health (Article } 120 \text { Constitution of 1972, amended 2004) and water concessions have to serve social welfare and public interest } \\
\text { (Article 259). }\end{array}$ \\
\hline Paraguay & LAW & The Water Law of 2007 acknowledges HRW. \\
\hline Peru & LAW & $\begin{array}{l}\text { Section } 3 \text { Water Law of } 2009 \text { states, that drinking water is a HR prioritized above all other uses. However, such HRW-commitment is not seen in the conflict about } \\
\text { pollution from the Yanacocha gold mine in Cajamarca [339]. }\end{array}$ \\
\hline Philippines & $\mathrm{CON}$ & $\begin{array}{l}\text { Water is state-property and the state is obliged to "beneficial use" of water supply ( } § 3 \text { Article } 12 \text { Constitution of 1987). Courts (\#78) applied also the right to health } \\
\text { ( }(15 \text { Article 3). }\end{array}$ \\
\hline South Africa & $\mathrm{CON}$ & Section 5.4 \\
\hline Sri Lanka & POL & HRW is acknowledged by the National Policy on Drinking Water of 2007. \\
\hline Tanzania & LAW & The Water Utilization Act of 1974 (revised 1993) acknowledges HRW for domestic needs. \\
\hline Tunisia & $\mathrm{CON}$ & The state guarantees HRW with a focus on rational use and conservation (Article 44 Constitution of 2014). \\
\hline Uganda & $\mathrm{CON}$ & The state endeavors HRW (Chapter 11 Constitution of 1995, amended 2005). \\
\hline $\begin{array}{l}\text { United } \\
\text { Kingdom }\end{array}$ & LAW & While England and Wales privatized their water sector, automatic disconnections were prohibited (\#106). In 2006 the government announced that it would recognize HRW. \\
\hline Uruguay & $\mathrm{CON}$ & Access to drinking water "is a basic HR" (Article 67 Constitution of 1967, amended 2002) and water provision is a public sector task (privatization is prohibited). \\
\hline USA & NO HRW & $\begin{array}{l}\text { Federal government opposed HRW, informing OHCHR that as a matter of principle the "United States does not share the view that a right to water exists under } \\
\text { international human rights law" [340], whereas HRW is accepted by California (California Bill } 685 \text { of 2013), though no longer with specific rights, as in a previous } \\
\text { proposal. De facto HRW is also accepted in water-related court rulings (\#109) and in actual policy making [341]. }\end{array}$ \\
\hline Venezuela & $\mathrm{CON}$ & The rights to health and to adequate housing are recognized (Articles 83 and 82 Constitution of 1999); courts confirmed this (\#110). \\
\hline Zambia & $\mathrm{CON}$ & The state endeavors HRW (Article 112 Constitution of 1998). \\
\hline
\end{tabular}

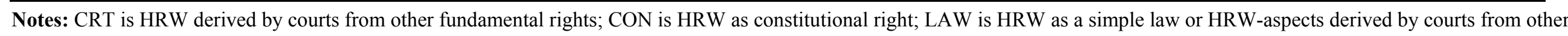
simple laws (e.g., consumer protection); POL is HRW as government policy or declaration; NO HRW is a borderline case for HRW, but not yet HRW. 


\section{References and Notes}

1. De Albuquerque, Catarina. "Report A/66/255 by UNO Special Rapporteur on the Right to Access to Safe Drinking Water and Sanitation.” 2011. Available online: http://daccess-dds-ny.un.org/ doc/UNDOC/GEN/N11/443/64/PDF/N1144364.pdf?OpenElement (accessed on 3 August 2015).

2. WHO, and UNICEF. "Progress on Drinking Water and Sanitation 2014 Update." Available online: http://www.who.int/water_sanitation_health/publications/2014/jmp-report/en/ (accessed on 31 July 2015).

3. Onda, Kyle, Joe LoBuglio, and Jamie Bartram. "Global Access to Safe Water: Accounting for Water Quality and the Resulting Impact on MDG Progress.” International Journal of Environmental Research \& Public Health 9 (2012): 880-94.

4. Cumming, Oliver, Mark Elliott, Alycia Overbo, and Jamie Bartram. "Does Global Progress on Sanitation Really Lag behind Water? An Analysis of Global Progress on Community-and Household-Level Access to Safe Water and Sanitation.” PlosOne 9 (2014): e114699.

5. Wescoat, James L., Lisa Headington, and Rebecca Theobald. "Water and Poverty in the United States." Geoforum 38 (2007): 801-14.

6. Montgomery, Maggie A., and Menachem Elimelech. "Water and Sanitation in Developing Countries: Including Health in the Equation." Environmental Science \& Technology 41 (2007): 17-24.

7. Sura, Dipika, Lorenz von Seidlein, Byomkesh Manna, Shanta Dutta, Alok K. Deba, Banwari Lal Sarkar, Suman Kanungo, Jacqueline L. Deen, Mohammad Ali, Deok Ryun Kim, and et al. "The malaria and typhoid fever burden in the slums of Kolkata, India: Data from a prospective community-based study." Tropical Medicine \& Hygiene 100 (2006): 725-33.

8. McDonald, David A. "No money, no service." Alternatives Journal 28 (2002): 16-20.

9. Sorenson, Susan B., Christiaan Morssink, and Paola A. Campos. "Safe access to safe water in low income countries: Water fetching in current times." Social Science \& Medicine 72 (2011): 1522-26.

10. Pickering, Amy J., and Jennifer Davis. "Freshwater availability and water fetching distance affect child health in Sub-Saharan Africa." Environmental Science \& Technology 46 (2012): 2391-97.

11. Nussbaum, Martha, and Amartya Sen. The Quality of Life. Oxford: Oxford University Press, 1993.

12. Kevany, Kathleen, and Donald Huisingh. "A review of progress in empowerment of women in rural water management decision-making processes." Journal of Cleaner Production 60 (2013): 53-64.

13. Havelaar, Arie, Ursula J. Blumenthal, Martin Strauss, David Kay, and Jamie Bartram. "Guidelines: The current position." In WHO Water Quality Guidelines, Standards and Health. Edited by Lorna Fewtrell and Jamie Bartram. London: IWA Publishing, 2001, pp. 18-42.

14. Solomon, Ethan B., Simon Yaron, and Karl R. Matthews. "Transmission of E. coli O157: H7 from contaminated manure and irrigation water to lettuce plant tissue and its subsequent internalization." Applied Environmental Microbiology 68 (2002): 397-400.

15. Starkl, Markus, Norbert Brunner, Priyanie Amerasinghe, Jampani Mahesh, Dinesh Kumar, Shyam R. Asolekar, Sahebrao Sonkamble, and et al. "Stakeholder Views, Financing and Policy Implications for Reuse of Wastewater for Irrigation: A Case from Hyderabad, India.” Water 7 (2015): 300-28. 
16. Baum, Rachel, Jeanne Luh, and Jamie Bartram. "Sanitation: A Global Estimate of Sewerage Connections without Treatment and the Resulting Impact on MDG Progress." Environmental Science \& Technology 47 (2013): 1994-2000.

17. European Environmental Agency. "Changes in wastewater treatment in regions of Europe between 1990 and 2012." 2013. Available online: http://www.eea.europa.eu/data-and-maps/figures/changesin-wastewater-treatment-in-regions-of-europe-between-1990-and-2 (accessed on 31 July 2015).

18. Starkl, Markus, Norbert Brunner, Magdalena Feil, and Andreas Hauser. "Ensuring Sustainability of Non-Networked Sanitation Technologies: An Approach to Standardization." Environmental Science \& Technology 49 (2015): 6411-18.

19. UNO. "General Assembly Resolution, UNO document A/RES/64/292 of 28.07.2010.” 2010. Available online: http://www.unhcr.org/cgi-bin/texis/vtx/refworld/rwmain/opendocpdf.pdf?reldoc= $\mathrm{y} \&$ docid $=4 \mathrm{cc} 926 \mathrm{~d} 72$ (accessed on 6 August 2015).

20. UNO. "Human Rights Council Resolution, UNO document A/HRC/15/L.14 of 24.09.2010.” 2010. Available online: http://daccess-dds-ny.un.org/doc/UNDOC/LTD/G10/163/09/PDF/G1016309. pdf?OpenElement (accessed on 6 August 2015).

21. Hardberger, Amy. "Whose Job Is It Anyway? Governmental Obligations Created by the Human Right to Water." Texas International Law Journal 41 (2006): 533-68.

22. McCaffrey, Stephen C. "A Human Right to Water: Domestic and International Implications." Georgetown International Environmental Law Review 5 (1992): 1-24.

23. Obani, Pedi, and Joyeeta Gupta. "The Evolution of the Right to Water and Sanitation: Differentiating the Implications." Review of European, Comparative \& International Environmental Law 24 (2014): 27-39.

24. Gleick, Peter H. “The Human Right to Water.” Water Policy 1 (1998): 487-503.

25. Howard, Guy, and Jamie Bartram. Domestic Water Quantity, Service Level, and Health. Geneva: World Health Organization, 2003.

26. Chenoweth, Jonathan. "Minimum water requirement for social and economic development." Desalination 229 (2008): 245-56.

27. Barraqué, Bernard. "Past and future sustainability of water policies in Europe." Natural Resources Forum 27 (2003): 200-11.

28. American Society of Civil Engineers (ASCE). US Infrastructure Report Card. Washington: ASCE, 2005.

29. Anderson, Michelle Wilde. "The New Minimal Cities.” Yale Law Journal 123 (2013): 1118-227.

30. District Court, Detroit, MI, USA, Lyda v City of Detroit, pending case.

31. Albuquerque, Catarina de, Philip Alston, and Leilani Farha. "Detroit: Disconnecting water from people who cannot pay-An affront to human rights." Paper presented at UNO Office of the High Commissioner of Human Rights, Geneva, Switzerland, 25 June 2014.

32. Pardy, Bruce. "The dark irony of international water rights." Pace Environmental Law (PELR) Review 28 (2011): 907-20.

33. Bakker, Karen. "The 'Commons' versus the 'Commodity': Alter-Globalization, Anti-Privatization and the Human Right to Water in the Global South." Antipode 39 (2007): 430-55.

34. Anand, Prathivadi Bhayankaram. "Right to Water and Access to Water." Journal of International Development 19 (2007): 511-26. 
35. Fry, James D. "International Human Rights Law in Investment Arbitration: Evidence of International Law's Unity.” Duke Journal of Comparative \& International Law 18 (2007): 77-149.

36. Davidson-Harden, Adam, Anil Naidoo, and Andi Harden. "The geopolitics of the water justice movement." Peace Conflict \& Development 11 (2007): 1-34.

37. Anonymous. "What price for the priceless: Implementing the justiciability of the right to water." Harvard Law Review 120 (2007): 1067.

38. McGraw, George S. "Defining and Defending the Right to Water and Its Minimum Core: Legal Construction and the Role of National Jurisprudence." Loyola University Chicago International Law Review 8 (2011): 101-31.

39. Mehta, Lyly. "Water and Human Development." World Development 59 (2014): 59-69.

40. Meier, Benjamin Mason, Jocelyn Getgen Kestenbaum, Georgia L. Kayser, Urooj Quezon Amjad, and Jamie Bartram. "Examining the Practice of Developing Human Rights Indicators to Facilitate Accountability for the Human Right to Water and Sanitation." Journal of Human Rights Practice 6 (2014): 159-81.

41. Kayser, Georgia L., Patrick Moriarty, Catarina Fonseca, and Jamie Bartram. "Domestic Water Service Delivery Indicators and Frameworks for Monitoring, Evaluation, Policy and Planning: A Review." International Journal of Environmental Research and Public Health 10 (2013): 4812-35.

42. Cingranelli, David L., and David L. Richards. "The Human Rights Dataset.” 2012. Available online: www.humanrightsdata.org (accessed on 31 July 2015).

43. World Bank. "Worldwide Governance Indicators, 2014 Update." 2014. Available online: www.govindicators.org (accessed on 31 July 2015).

44. Kaufmann, Daniel, Aart Krary, and Massimo Mastruzzi. "The worldwide governance indicators: A summary of methodology, data and analytical issues. World Bank Policy Research Working Paper No. 5430." 2010. Available online: http://papers.ssrn.com/sol3/papers.cfm?abstract_id=1682130 (accessed on 31 July 2015).

45. Roberts, Susan M., Sarah Wright, and Phillip O'Neill. "Good Governance in the Pacific? Ambivalence and Possibility." Geoforum 38 (2007): 967-84.

46. The Fund for Peace. "The Failed States Index 2013." 2013. Available online: http://library. fundforpeace.org/fsi13 (accessed on 31 July 2015).

47. FAO. "Water resource information by country/territory and MDG Water Indicator, based on FAO-AQUASTAT database." 2010. Available online: http:/www.fao.org/nr/water/aquastat/maps/ AQUASTAT_water_resources_and_MDG_water_indicator_March_2013.pdf (accessed on 31 July 2015).

48. FitzGibbon, John, and Kenneth O. Mensah. "Climate change as a wicked problem." Sage Open 2 (2012): 1-22.

49. Wikipedia. "List of political and geographical borders." 2015. Available online: en.wikipedia.org/ wiki/List_of_political_and_geographic_borders (accessed on 31 July 2015).

50. UNESCO. “The United Nations World Water Development Report 2014: Water and Energy." Paper presented at UNO World Water Assessment Program at UNESCO, Paris, France, 2015.

51. WHO. Drinking Water Equity, Safety and Sustainability. New York: WHO \& UNICEF, 2011. 
52. Starkl, Markus, Norbert Brunner, and Thor-Axel Stenström. "Why do Water and Sanitation Systems for the Poor still Fail? Policy Analysis in Economically Advanced Developing Countries." Environmental Science \& Technology 47 (2013): 6102-10.

53. Ishaku, Hassan Tsenbeya, Ajayi Peters Abayomi, Abdulrahman Ahmed Sahabo, and Fabian Mazawuje Dama. "Complementing Water Supply through Rainwater Harvesting in Some Selected Villages of Sahel Savannah Ecological Zone in Borno State, North-Eastern Nigeria." Journal of Water Resource and Protection 5 (2013): 200-7.

54. Hunter, Paul R., Denis Zmirou-Navier, and Philippe Hartemann. "Estimating the impact on health of poor reliability of drinking water interventions in developing countries." Science of the Total Environment 407 (2009): 2621-24.

55. Araral, Eduardo, and David Yu. "Asia Water Governance Index." 2010. Available online: http://kyspp.nus.edu.sg/iwp/wp-content/uploads/sites/3/2013/04/AWGI-brochure-IWP-LKYSPP910.pdf (accessed on 31 July 2015).

56. Ostrom, Elinor. Governing the Commons: The Evolution of Institutions for Collective Action. Cambridge: Cambridge University Press, 1990.

57. Saleth, Maria, and Ariel Dinar. The Institutional Economics of Water: A Cross Country Analysis of Institutions and Performance. Cheltenham: Elgar Publishing, 2004.

58. Araral, Eduardo, and David J. Yu. "Comparative water law, policies, and administration in Asia: Evidence from 17 countries." Water Resources Research 49 (2013): 5307-16.

59. Boussard, Helene, Vivien Deloge, Laura van de Lande, and Hannah Neumeyer. "The Human Rights to Water and Sanitation in Courts Worldwide: A Selection of National, Regional and International Case-Law.” 2014. Available online: http://www.waterlex.org/?post_publications =the-human-rights-to-water-and-sanitation-in-courts-worldwide (accessed on 31 July 2015)

60. The Rights to Water and Sanitation. "Right to Water and Sanitation Information Portal." Available online: www.righttowater.info/progress-so-far/national-legislation-on-the-right-to-water/ (accessed on 1 August 2014).

61. Starkl, Markus, Norbert Brunner, Eduardo Lopez, and Jose L. Martinez-Ruiz. "A planning-oriented sustainability assessment framework for peri-urban water management in developing countries." Water Research 47 (2013): 7175-83.

62. Merrett, Stephen. "Deconstructing households' willingness-to-pay for water in low-income countries." Water Policy 4 (2002): 157-72.

63. Hanemann, W. Michael, and Barbara Kanninen. "The Statistical Analysis of Discrete-Response CV Data." In Valuing Environmental Preferences: Theory and Practice of the Contingent Valuation Method in the US, EU and Developing Countries. Edited by Ian J. Bateman, Kenneth George Willis and Kenneth J. Arrow. Oxford: Oxford University Press, 1999, pp. 302-441.

64. Bateman, Ian J., and Ian H. Langford. "Budget Constraint, Temporal, and Question-Ordering Effects in Contingent Valuation Studies.” Environment and Planning A 29 (1997): 1215-28.

65. Li, Hui, Robert P. Berrens, Alok K. Bohara, Hank C. Jenkins-Smith, Carol L. Silva, and David L. Weimer. "Testing for Budget Constraint Effects in a National Advisory Referendum on the Kyoto Protocol.” Journal of Agricultural and Resource Economics 30 (2005): 350-66. 
66. Liebe, Ulf, Peter Preisendörfer, and Jürgen Meyerhoff. “To Pay or Not to Pay: Competing Theories to Explain Individuals' Willingness to Pay for Public Environmental Goods.” Environment and Behavior 43 (2011): 106-30.

67. Arrow, Kenneth J., Robert Solow, Paul R. Portney, Edward E. Leamer, Roy Radner, and E. Howard Schuman. "Report of the NOAA panel on contingent valuation." Federal Register 58 (1993): 4602-14.

68. Mitchell, Robert C., and Richard T. Carson. Using Surveys to Value Public Goods: The Contingent Valuation Method. Washington: Resources for the Future, 1989.

69. Casella, George, and Roger L. Berger. Statistical Inference. Stamford: Thomson Learning, 2001.

70. Kerr, Geoffrey N. "Dichotomous Choice Contingent Valuation Probability Distributions." Australian Journal of Agricultural and Resource Economics 44 (2000): 235-52.

71. Fisher, Walter D. "On grouping for maximum homogeneity." Journal of the American Statistical Association 53 (1958): 789-98.

72. Doepke, Mathias, and Michele Tertilt. “Women's Liberation: What's in it for Men?" Quarterly Journal of Economics 124 (2009): 1541-91.

73. Lee, John. "The Underlying Legal Theory to Support a Well-Defined Human Right to a Healthy Environment as a Principle of Customary International Law." Columbia Journal of Environmental Law 25 (2000): 283-341.

74. Nowak, Manfred. "Introduction to Human Rights Theory.” In All Human Rights for All. Edited by Manfred Nowak, Karolina M. Januszewski and Tina Hofstätter. Vienna: NWV publishing, 2012, pp. 269-78. This article explains the classification of first, second, and third generation HR and the distinction of the dimensions respect, protect, fulfil.

75. Hathaway, Oona A. "Do Human Rights Treaties Make a Difference?" Yale Law Journal 111 (2002): 1935-2042.

76. Hafner-Burton, Emilie M., and Kiyoteru Tsutsui. "Human Rights in a Globalizing World: The Paradox of Empty Promises.” American Journal of Sociology 111 (2005): 1373-411.

77. Neumayer, Eric. "Do International Human Rights Treaties Improve Respect for Human Rights?" Journal of Conflict Resolution 49 (2005): 925-53.

78. Magesan, Arvind. "Human Rights Treaty Ratification of Aid Receiving Countries." World Development 45 (2013): 175-88.

79. Example: OPCAT, the Optional Protocol to CAT, adopted on 18.12.2002 at the 57th Session of UNO-General-Assembly by resolution A/RES/57/199, entered into force on 22.06.2006; see OHCHR Treaty-Page.

80. Cole, Wade M. "Hard and Soft Commitments to Human Rights Treaties, 1966-2000." Sociological Forum 24 (2009): 563-88.

81. Crootof, Rebecca. "Judicious Influence: Non-Self-Executing Treaties and the Charming Betsy Canon." Yale Law Journal 120 (2011): 1784-819.

82. SCt USA, Lawrence v Texas of 26.06.2003, discussed case-law of ECtHR.

83. Indian Kanoon. "Indian case law database." 2015. Available online: http://indiankanoon.org/ (accessed on 31 July 2015). This database lists ca. $150 \mathrm{SCt}$ India cases referring to ECHR. Conversely, ECtHR cited SCt India in e.g., Hämäläinen v Finland of 16.07.2014 or GB v Bulgaria of 11.03.2004. 
84. Wendland, Lene. A Handbook of State Obligations under the UN Convention against Torture. Geneva: APT, 2002.

85. Similar regulations protect prisoners of war: International Criminal Tribunal for former Yugoslavia, Appellate Chamber, Prosecutor v Mucic, Delic \& Landzo of 08.04.2003.

86. HRCe, Cabal \& Pasini v Australia of 07.08.2003.

87. UNO Committee for the Elimination of Discrimination against Women, Da Silva Pimentel v Brazil of 25.07.2011.

88. The very first case under CRPD has been closed recently (UNO Committee on the Right of Persons with Disabilities, HMv Sweden of 19.04.2012) and for CESCR the Optional Protocol entered into force in 2013.

89. McCaffrey, Stephen C., and Kate J. Neville. "Small Capacity and Big Responsibilities: Financial and Legal Implications of a Human Right to Water for Developing Countries." Georgetown International Environmental Law Review 21 (2008): 679-704.

90. Courtis, Christian, and Magdlena Sepúlveda. “Are Extra-Territorial Obligations Reviewable under the Optional Protocol to the ICESCR?” Nordisk Tidsskrift for Menneskerettigheter 27 (2009): 54-63.

91. Khalfan, Ashfaq. "Development Cooperation and Extraterritorial Obligations." In The Right to Water: Theory, Practice and Prospects. Edited by Malcolm Langford and Anna Russell. Cambridge: CUP, 2012.

92. Article 12 of the ILO Technical Convention Concerning Hygiene in Commerce and Offices of 1964 (ratified by 51 countries) mentions HRW at the workplace. However, only certain organizations may complain to the ILO treaty-bodies.

93. UNO. "UNO document CERD/C/ITA/CO/15 of 04.03.2008." 2008. Available online: http://tbinternet.ohchr.org/_layouts/treatybodyexternal/Download.aspx?symbolno=CERD\%2FC $\% 2$ FITA\%2FCO\%2F15\&Lang=en (accessed on 6 August 2015).

94. UNO. "UNO document CEDAW/C/ETH/CO/6-7 of 29.07.2011." 2011. Available online: http://tbinternet.ohchr.org/_layouts/treatybodyexternal/Download.aspx?symbolno=CEDAW/C/ETH/ CO/6-7\&Lang=En (accessed on 6 August 2015).

95. UNO. "UNO document E/C.12/PER/CO/2-4 of 18.05.2012." 2012. Available online: http://tbinternet.ohchr.org/_layouts/treatybodyexternal/Download.aspx?symbolno=E/C.12/PER/C $\mathrm{O} / 2-4 \&$ Lang=En (accessed on 6 August 2015).

96. UNO. "UNO document E/C.12/NZL/CO/3 of 18.05.2012." 2012. Available online: http://tbinternet.ohchr.org/_layouts/treatybodyexternal/Download.aspx?symbolno=E/C.12/NZL/ $\mathrm{CO} / 3 \&$ Lang $=$ En (accessed on 6 August 2015).

97. UNO. "UNO document $\mathrm{CRC} / \mathrm{C} / \mathrm{KEN} / \mathrm{CO} / 2$ of 02.02.2007." 2007. Available online: http://tbinternet.ohchr.org/_layouts/treatybodyexternal/Download.aspx?symbolno=CRC/C/KEN/ $\mathrm{CO} / 2 \&$ Lang=En (accessed on 6 August 2015).

98. UNO. "UNO document CRPD/C/SLV/CO/1 of 13.09.2013." 2013. Available online: http://tbinternet.ohchr.org/_layouts/treatybodyexternal/Download.aspx?symbolno=CRPD/C/SLV /CO/1\&Lang=Sp (accessed on 6 August 2015).

99. UNO. "UNO document $\mathrm{CMW} / \mathrm{C} / \mathrm{BIH} / \mathrm{CO} / 2$ of 26.09.2012." 2012. Available online: http://tbinternet.ohchr.org/_layouts/treatybodyexternal/Download.aspx?symbolno $=\mathrm{CMW} / \mathrm{C} / \mathrm{BIH} /$ CO/2\&Lang=En (accessed on 6 August 2015). 
100. UNO. "UNO document A/HRC/RES/5/1 of 18.07.2007." 2007. Available online: http://ap.ohchr.org/documents/E/HRC/resolutions/A_HRC_RES_5_1.doc (accessed on 6 August 2015).

101. It was created by UNO-General-Assembly Resolution 60/251 of 15.03 .2006 to establish the HR-Council, which (by October 2011) has reviewed the HR-records of all 193 UNO member-states.

102. International Court of Justice, Argentina v Uruguay concerning pulp mills on the River Uruguay of 20.04.2010.

103. Meshel, Tamar. "Human Rights in Investor-State Arbitration: The Human Right to Water and Beyond." Journal of International Dispute Settlement 6 (2015): 277-307.

104. Hohenwarter, Bettina. Das Recht auf Wasser. Die menschenrechtliche Verantwortung von Staaten und Unternehmen. Vienna: Publishing NWP, 2014.

105. ACnHPR, SERAC \& CESR v Nigeria of 27.10.2001

106. Moriarty, Brid, and Eva Massa. Human Rights Law. Oxford: Oxford University Press, 2012.

107. García San José, D. La Protection de l'Environnement et la Convention Européenne des Droits de l'Homme. Strasbourg: Council of Europe, 2005.

108. PACE. "Drafting an additional protocol to the European Convention on Human Rights concerning the right to a healthy environment." 2009. Available online: http://www.coe.int/t/dghl/standardsetting/ hrpolicy/other_committees/GT-DEV-ENV_docs/erec1885.pdf (accessed on 31 July 2015).

109. Examples: European Agreement on the Restriction of the Use of certain Detergents in Washing and Cleaning Products; European Landscape Convention.

110. Shany, Yuval. Assessing the Effectiveness of International Courts. Oxford: Oxford University Press, 2014.

111. ECtHR published case-law research reports about the use of Council of Europe treaties (2011) and about references to the Inter-American system (2012).

112. African Human Rights Case-Law Analyzer. “African regional case law database.” 2015. Available online: http://caselaw.ihrda.org/ (accessed on 31 July 2015).

113. 111,163 cases decided in 2014 , of them 2388 judgments about the merits; the other applications struck out of the list or declared inadmissible administratively (law clerks decide) or by a "judicial formation"; source: ECtHR, 2014 case statistics.

114. Pasqualucci, Jo M. The Practice and Procedure of the IACtHR. Cambridge: Cambridge University Press, 2003.

115. Schulze, Erika. "Supranational decision-making procedures." 2015. Available online: www.europarl.europa.eu/ftu/pdf/en/FTU_1.4.1.pdf (accessed on 8 March 2015).

116. Josefsson, Henrik. “Achieving Ecological Objectives.” Laws 1 (2012): 39-63.

117. Taborowski, Maciej. "Infringement Proceedings and Non-Compliant National Courts." Common Market Law Review 49 (2012): 1881-914.

118. González-Salzberg, Damián A. "Economic and social rights within the Inter-American Human Rights System: Thinking new strategies for obtaining judicial protection.” Revista Colombiana de Derecho Internacional 18 (2011): 117-54.

119. Shany, Yuval. "Toward a General Margin of Appreciation Doctrine in International Law?" European Journal of International Law 16 (2005): 907-40. 
120. Kemp, Deanna, Carol J. Bond, Daniel M. Franks, and Claire Cote. "Mining, water and human rights: Making the connection.” Journal of Cleaner Production 18 (2010): 1553-62.

121. Morinville, Cynthia, and Lucy Rodina. "Rethinking the human right to water: Water access and dispossession in Botswana's Central Kalahari Game Reserve." Geoforum 49 (2013): 150-59.

122. Retherford, Kristin L. "Regulating the Corporate Tap: Applying Global Administrative Law Principles to Achieve the Human Right to Water." Indiana Law Journal 88 (2013): 811-35.

123. OECD. "Guidelines for Multinational Enterprises." 1976. Available online: http://mneguidelines.oecd.org/ (accessed on 31 July 2015). The Guidelines were adopted in 1976 and updated 2011 under participation of business, labor, NGOs, non-adhering countries and international organizations.

124. Linder, Barbara, and Astrid Steinkellner. "Corporate Responsibility for Human Rights." In All Human Rights for All. Edited by Manfred Nowak, Karolina M. Januszewski and Tina Hofstätter. Vienna: NWV publishing, 2012, pp. 577-83.

125. Tribunal Latino Americano del Agua. "Case law information.” 2015. Available online: tragua.com (accessed on 31 July 2015).

126. White, Lisa, and Bram F. Noble. "Strategic environmental assessment for sustainability: A review of a decade of academic research." Environmental Impact Assessment Review 42 (2013): 60-66.

127. Larson, Rhett B. “The New Right to Water." Washington and Lee Law Review 70 (2013): 2181-67.

128. Salman, Salman, and Siobhán McInerney-Lankford. The Human Right to Water: Legal and Policy Dimensions. Washington: World Bank, 2004.

129. Letsas, George. "The ECHR as a living instrument: Its meaning and legitimacy." In Constituting Europe, the European Court of Human Rights in National, European and Global Context. Edited by Andreas Føllesdal, Birgit Peters and Geir Ulfstein. Cambridge: University Press, 2010, pp. 106-41.

130. Kiefer, Thorsten, Laura van de Lande, Heidi Adler-Michaelson, Hannah Neumeyer, Ashfaq Khalfan, Virginia Roaf, Danielle Morley, Mary O’Connell, Ceridwen Johnson, Isabella Montgomery, and Jean-Benoit Charrin, eds. The Human Right to Safe Drinking Water and Sanitation in Law and Policy-A Sourcebook. Berlin: WASH United, 2012.

131. Wutich, Amber, Abigail M. York, Alexandra Brewis, Rhian Stotts, and Christopher M. Roberts. "Shared cultural norms for justice in water institutions: Results from Fiji, Ecuador, Paraguay, New Zealand, and the U.S.” Journal of Environmental Management 113 (2012): 370-76.

132. Noga, Jacqueline, and Gregor Wolbring. "Perceptions of Water Ownership, Water Management, and the Responsibility of Providing Clean Water." Water 5 (2013): 1865-89.

133. Russell, Anna F. S. "International Organizations and Human Rights: Realizing, Resisting or Repackaging the Right to Water?” Journal of Human Rights 9 (2010): 1-23.

134. Bosselmann, Klaus. "A vulnerable environment: Contextualising law with sustainability.” Journal of Human Rights and the Environment 2 (2011): 45-63.

135. Narain, Vrinda. "Water as a fundamental right: A perspective from India." Vermont Law Review 34 (2009): 917-26.

136. Sax, Joseph L. "The Public Trust Doctrine in Natural Resource Law: Effective Judicial Intervention." Michigan Law Review 68 (1970): 471-566. 
137. UNO. "UNO document CERD/C/IND/CO/19 of 06.03.2007." 2007. Available online: http://tbinternet.ohchr.org/_layouts/treatybodyexternal/Download.aspx?symbolno=CERD/C/IND /CO/19\&Lang=En (accessed on 6 August 2015).

138. UNO. "UNO document CEDAW/C/IND/CO/SP.1 of 03.09.2010." 2010. Available online: http://tbinternet.ohchr.org/_layouts/treatybodyexternal/Download.aspx?symbolno=CEDAW\%2F C\%2FIND\%2FCO\%2FSP.1\&Lang=en (accessed on 6 August 2015).

139. Samra, Shamsher, Julia Crowley, and Mary C. Smith Fawzi. "The right to water in rural Punjab: Assessing equitable access to water in the context of the ongoing Punjab Rural Water Supply Project." Health \& Human Rights 13 (2011): E36-49.

140. UNO. "UNO document E/C.12/IND/CO/5 of 08.08.2008 at $\S \S 8,34$ and 74. 2008." 2008. Available online http://www.google.at/url? $\mathrm{sa}=\mathrm{t} \& \mathrm{rct}=\mathrm{j} \& \mathrm{q}=\& \mathrm{esrc}=\mathrm{s} \&$ source $=\mathrm{web} \& \mathrm{~cd}=1 \&$ ved $=0$ CB8QFjAAahUKEwig6efitpTHAhVMsxQKHXDJBts\&url=http\%3A\%2F\%2Fwww2.ohc hr.org\%2Fenglish\%2Fbodies\%2Fcescr\%2Fdocs\%2Fco\%2FE.C.12.IND.CO.5.doc\&ei=Ak_DVa DgJszmUvCSm9gN\&usg=AFQjCNHrycSNQEmBSi8Ew9ptTMN0jQB7Cg (accessed on 6 August 2015).

141. Brocklehurst, Clarissa, Amrit Pandurangi, and Latha Ramanathan. "Tariff Subsidies in South Asia: Tariff Structures in Six South Asian Cities: Do They Target Subsidies Well?" In Water Tariffs and Subsidies in South Asia. Washington: World Bank, 2002.

142. Srinath, Pavan. "Let India's urban poor pay for good water." Hindustan Times, 13 February 2015. Available online: http://www.livemint.com/Opinion/xbu06pHKpBzICZ1THPisZJ/Let-Indias-urbanpoor-pay-for-good-water.html?facet=print (accessed on 8 March 2015).

143. Zetland, David, and Christopher Gasson. "A global survey of urban water tariffs: Are they sustainable, efficient and fair?" International Journal of Water Resources Development 29 (2013): $327-42$.

144. All India Institute of Local Self-Government (AIILSG). Burhanpur City Sanitation Plan. Bhopal: Government Madhya Pradesh, 2010.

145. Centre for Environmental Management and Decision Support (CEMDS). Raisen City Sanitation Plan. London: Water Aid, 2010.

146. Raje, Dinesh V., Poornima S. Dhobe, and Amol W. Deshpande. "Consumer's willingness to pay more for municipal supplied water: A case study." Ecological Economics 42 (2002): 391-400.

147. Households with WTP above the charge were assumed to pay the charge, while those with WTP below the charge were assumed to pay nil. In actual implementation, they will be connected and the municipality has to decide on a case-to-case basis, if part of the charges is waived for them. Optimal charges ranged from 70-100 INR for Burhanpur and 90-120 INR for Raisen (conservative estimates from the upper 95\%-confidence limits of WTP). In Raisen respondents had incentives to state higher WTP, as Mishra Talaab is a pond of religious value.

148. Anonymous. "India's median per capita income lowest among BRICS: Gallup.” 2013. Available online: www.business-standard.com/article/economy-policy/india-s-median-per-capita-incomelowest-among-brics-gallup-113121600968_1.html (accessed on 31 July 2015).

149. Brunner, Norbert, Ashwini Lele, Markus Starkl, and Laura Grassini. "Water sector reform policy of India: Experiences from case studies in Maharashtra." Journal of Policy Modeling 32 (2010): 544-61. 
150. Muller, Helgard. "The South African Experience on Legal, Institutional and Operational Aspects of the Rights to Water and Sanitation." Aquatic Procedia 2 (2014): 35-41.

151. Ward, Frank A., and Manuel Pulido-Velazquez. "Incentive pricing and cost recovery at the basin scale." Journal of Environmental Management 90 (2009): 293-313.

152. Brunner, Norbert, Laura Essl, Teddy Gounden, Sdu Mbata, Nosipho Ngubane, and Markus Starkl. "Are Roof Tanks Pro-Poor Service Levels? A Case Study from EThekwini (Durban), South Africa." Paper presented at Third African Conference on Water Resource Management (Africa WRM 2010), Gabarone, Botswana, September 2010.

153. Dugard, Jackie. "Judging the Judges: Towards an Appropriate Role for the Judiciary in South Africa's Transformation.” Leiden Journal of International Law 20 (2007) 965-81.

154. Fendorf, Scott, Holly A. Michael, and Alexander van Geen. "Spatial and Temporal Variations of Groundwater Arsenic in South and Southeast Asia." Science 328 (2010): 1123-27.

155. Martinez-Alier, Joan, Isabelle Anguelovski, Patrick Bond, Daniela Del Bene, Federico Demaria, Julien-Francois Gerber, Lucie Greyl, Willi Haas, Hali Healy, Victoria Marín-Burgos, and et al. "Between activism and science: Grassroots concepts for sustainability coined by Environmental Justice Organizations.” Journal of Political Ecology 21 (2014): 20-60.

156. Brunner, Norbert, Markus Starkl, Ponnusamy Sakthivel, Lakshmanan Elango, Subbaiah Amirthalingam, Chinniyampalayam E Pratap, Munuswamy Thirunavukkarasu, and Sundaram Parimalarenganayaki. "Policy Preferences about Managed Aquifer Recharge for Securing Sustainable Water Supply to Chennai City, India." Water 6 (2014): 3739-57.

157. Bustamante, Rocio. "The water war: Resistance against privatization of water in Cochabamba, Bolivia." Revista de Gestión Del Agua en América Latina 1 (2004): 37-46.

158. Harris, Leila M., and María Cecilia Roa-García. "Recent waves of water governance: Constitutional reform and resistance to neoliberalization in Latin America (1990-2012)." Geoforum 50 (2013): 20-30.

159. Domènech, Laia, Hug March, and David Saurí. "Contesting large-scale water supply projects at both ends of the pipe in Kathmandu and Melamchi Valleys, Nepal." Geoforum 47 (2013): 22-31.

160. Flynn, Sean, and Danwood M. Chirwa. "The Constitutional Implications of Commercializing Water in South Africa." In The Age of Commodity: Water privatization in Southern Africa. Edited by David Alexander McDonald and Greg Ruiters. London: Earthscan, 2005, pp. 59-77.

161. Paul, Tara E. "Plugging the Democracy Drain in the Struggle for Universal Access to Safe Drinking Water.” Indiana Journal of Global Legal Studies 20 (2013): 469-503.

162. Walker, Gordon. "Environmental justice, impact assessment and the politics of knowledge." Environmental Impact Assessment Review 30 (2010): 312-18.

163. Miranda, Nicholas. "Concession Agreements: From Private Contract to Public Policy." Yale Law Journal 117 (2007): 510-49.

164. Murthy, Sharmila L. "The Human Right(s) to Water and Sanitation: History, Meaning, and the Controversy over Privatization." Berkeley Journal of International Law 31 (2013): 89-147.

165. Gebauer, Heiko, and Caroline Jennings Saul. "Business model innovation in the water sector in developing countries." Science of the Total Environment 488 (2014): 412-520. 
166. Galiani, Sebastian, Paul Gertler, and Ernesto Schargrodsky. "Water for Life: The Impact of the Privatization of Water Services on Child Mortality." Journal of Political Economy 113 (2005): 83-120.

167. Molinos-Senante, María, and Ramón Sala-Garrido. "The impact of privatization approaches on the productivity growth of the water industry: A case study of Chile.” Environmental Science \& Policy 50 (2015): 166-79.

168. Hermes, Niels, and Robert Lensink. "Changing the conditions for development aid: A new paradigm?” Journal of Development Studies 37 (2001): 1-16.

169. Tsagarakis, Konstantinos P. "New directions in water economics, finance and statistics." Water Science \& Technology: Water Supply 5 (2005): 1-15.

170. Bel, Germà, Xavier Fageda, and Mildred E. Warner. "Is Private Production of Public Services Cheaper than Public Production? A meta-regression analysis of solid waste and water services." Journal of Policy Analysis and Management 29 (2010): 553-77.

171. Schiffler, Manuel. Water, Politics, and Money: A Reality Check on Privatization. Cham ZG: Springer International Publishing, 2015.

172. Whittington, Dale. "What have we learned from twenty years of stated preference studies in less developed countries?” Annual Review of Resource Economics 2 (2010): 209-36.

173. Vásquez, William F, Pallab Mozumder, Jesús Hernández-Arce, and Robert P. Berrens. "Willingness to pay for safe drinking water: Evidence from Parral, Mexico.” Journal of Environmental Management 90 (2009): 3391-400.

174. Mazumdar, Sumit, and Madappa Guruswamy. "Demand and Willingness to Pay for Health Care in Rural West Bengal.” Social Change 39 (2009): 568-85.

175. International Federation of Health Plans. "2011 Comparative Price Report; Variation in Medical and Hospital Prices by Country." 2012. Available online: http://www.ifhp.com.documents/ 2011IFHPPriceReportGraphs_version3.pdf (accessed on 20 February 2015).

176. Komatsu, Satoru, Shunji Matsuoka, and Katsuya Tanaka. "Estimating Willingness to Pay for Rural Water Supply Improvements for Pasture Land Conservation in Mongolia.” Master Thesis, Hiroshima University, Hiroshima, Japan, 20 February 2007.

177. Fujita, Yasuo, Ayumi Fujii, Shigeki Furukawa, and Takehiko Ogawa. "Estimation of Willingness-to-Pay for Water and Sanitation Services through Contingent Valuation Method: A Case Study in Iquitos City, the Republic of Peru.” Japan Bank for International Cooperation Research Review 11 (2005): 59-87.

178. He, Xue Dong. Closed-Form Solutions to Dynamic Pricing Problems with Cauchy-Type-Tailed Willingness-to-Pay. New York: Columbia University Press, 2014.

179. Derunova, Elena Anatol'evna, Anna Alexandrovna Firsova, Alla Vladimirovna Vavilina, and Alexander Sergeevich Semenov. "The Study of the Dynamics of Innovative Development of Economy on the Endogenous Growth through Multi-sector Extension of the Solow Model." Biosciences Biotechnology Research Asia 11 (2014): 1581-89.

180. Shah, Tushaar. "Towards a managed aquifer recharge strategy for Gujarat, India: An economist's dialogue with hydro-geologists." Journal of Hydrology 518 (2014): 94-107. Beyond energy subsidies, there are many other factors linking irrigation and drinking water supply. It is not the focus of this paper to explore them. 
181. World Bank. "World Development Report 2015." Available online: http://www.worldbank.org/ content/dam/Worldbank/Publications/WDR/WDR\%202015/WDR-2015-Full-Report.pdf (accessed on 31 July 2015).

182. Tsagarakis, Konstantinos P. "Does Size Matter? Operating Cost Coverage for Water Utilities." Water Resources Management 27 (2013): 1551-62.

183. Hanemann, W. Michael. "The Economic Conception of Water.” In Water Crisis: Myth or Reality? Edited by Peter P. Rogers, M. Ramón Llamas and Luis Martinez Cortina. London: Taylor \& Francis, 2006, pp. 81-92.

184. Bain, Robert, Jim A. Wright, Elizabeth Christenson, and Jamie Bartram. "Rural/urban inequalities in post 2015 targets and indicators for drinking-water." Science of the Total Environment 490 (2014): 509-13.

185. Davis, Jennifer. "Corruption in public service delivery: Experience from South Asia's water and sanitation sector." World Development 32 (2004): 53-71.

186. Subhrendu K. Pattanayak, Jui-Chen Yang, Katherine L. Dickinson, Christine Poulos, Sumeet R. Patil, Ranjan K. Mallick, Jonathan L. Blitstein, and Purujit Praharaj. "Shame or subsidy revisited: Social mobilization for sanitation in Orissa, India." Bulletin of the World Health Organization 87 (2009): 580-87.

187. Okun, Daniel A. "The Value of Water and Sanitation in Development: An Assessment." American Journal of Public Health 78 (1988): 1463-67.

188. Garcia, Kelli K., and Lawrence O. Gostin. “One Health, One World-The Intersecting Legal Regimes of Trade, Climate Change, Food Security, Humanitarian Crises, and Migration.” Laws 1 (2012): 4-38.

189. Mueller, Dennis C. Public Choice III. Cambridge: Cambridge University Press, 2003.

190. Starkl, Markus, Norbert Brunner, Werner Flögl, and Johann Wimmer. "Design of an institutional decision-making process: The case of urban water management." Journal of Environmental Management 90 (2009): 1030-42.

191. Rodgers, Ann F., Lydia A. Ajono, John O. Gyapong, Maria Hagan, and Paul M. Emerson. "Characteristics of latrine promotion participants and non-participants; inspection of latrines and perceptions of household latrines in Northern Ghana." Tropical Medicine \& International Health 12 (2007): 772-82.

192. World Bank. Improving Municipal Management for Cities to Succeed: An Independent Evaluation Group Special Study. New York: World Bank, 2009.

193. Asian Human Rights Commission. "The State of Human Rights in Nepal in 2011.” 2013. Available online: http://tbinternet.ohchr.org/Treaties/CCPR/Shared\%20Documents/NPL/INT_CCPR_NGO_ NPL_14604_E.pdf (accessed on 31 July 2015).

194. Dhungel, Dwarika Nath, and Mahendra Raj Sapkota. "Decentralization in Nepal: Laws and Practices.” 2011. Available online: http://www.nibr.no/filer/2011-23.pdf (accessed on 31 July 2015).

195. Prokopy, Linda Stalker. "The relationship between participation and project outcomes: Evidence from rural water supply projects in India." World Development 33 (2005): 1801-19.

196. Chattopadhyay, Raghabendra, and Esther Duflo. "Women as Policy Makers: Evidence from a Randomized Policy Experiment in India.” Econometrica 72 (2004): 1409-43. 
197. De Albuquerque, Catarina. "Report A/HRC/24/44 by UNO Special Rapporteur on the right to access to safe drinking water and sanitation.” 2013. Available online: http://www.ohchr.org/EN/ HRBodies/HRC/RegularSessions/Session24/Documents/A-HRC-24-44_en.pdf (accessed on 3 August 2015).

198. Brunner, Norbert, and Markus Starkl. "Financial and economic determinants of collective action: The case of wastewater management." Environmental Impact Assessment Review 32 (2012): 140-50.

199. Austrian Court of Auditors. "Stadt Wien; Wasser-, Kanal- und Müllgebühren sowie Energiepreise (in German).” 2010. Available online: http://www.rechnungshof.gv.at/fileadmin/downloads/ 2010/berichte/teilberichte/wien/wien_2010_02/Wien_2010_02_1.pdf (accessed on 30 July 2015).

200. Smith, Richard. 'The Margin of Appreciation and Human Rights Protection in the 'War on Terror': Have the Rules Changed before the European Court of Human Rights?" 2011. Available online: http://projects.essex.ac.uk/ehrr/V8N1/Smith.pdf (accessed on 30 July 2015).

201. ACnHPR, Institute for Human Rights \& Development in Africa v Angola of 22.05.2008.

202. International Centre for the Settlement of Investment Disputes, Suez, Vivendi \& AWG v Argentina of 30.07.2010, Case No. ARB/03/19.

203. SCt Argentina, National Ombudsman v National Government (Defensor del Pueblo de la Nacion c Estado Nacional) of 18.09.2007.

204. Moreno Peace Court, Argentina, Usuarios y Consumidores en Defensa de sus Derechos Asociación Civil v AGBA of 21.08.2002.

205. ECtHR, Tadevosyan v Armenia of 02.12.2008.

206. Austria, Statistik. "Bruttojahreseinkommen der unselbständig Erwerbstätigen 1997 bis 2013." 2014. Available online: http://www.statistik.at (accessed on 31 July 2015).

207. HRCe, Pohl v Austria of 23.08.2004.

208. SCt Bangladesh, Mohiuddin Farooque v Government of Bangladesh of 15.07.2001, Writ Petition 891/1994.

209. SCt Bangladesh, Sindh Institute v Nestle Milkpak of 30.11.2004, High Court Division.

210. SCt Bangladesh, Bangladesh Society for the Enforcement of Human Rights \& Others $v$ Government of 14.03.2000, High Court Division.

211. ECtHR, MSS v Belgium and Greece of 21.01.2011.

212. Langford, Lillian M. "The Other Euro Crisis: Rights Violations under the Common European Asylum System and the Unraveling of EU Solidarity." Harvard Human Rights Journal 26 (2013): 217-64.

213. ECtHR, Riad \& Idiab v Belgium of 24.01.2008.

214. ECtHR, L"Erablière ASBL v Belgium of 24.02.2009.

215. ECtHR, Hamer v Belgium of 27.11.2007.

216. Belgian Constitutional Court (Court of Arbitration), Municipality of Wemmel v Flemish Council of 01.04.1998.

217. Court of Appeal, Lobatse, Botswana, Mosetlhanyane v Attorney General of 27.01.2011, Civil Appeal CACLB-074-10.

218. IACnHR, Yanomani Indian Community v Brazil of 05.03.1985.

219. Brazil Superior Court of Justice, Manoel Pereira v CASAN of 20.04.1999.

220. HRCe, Naidenova v Bulgaria of 27.11.2012. 
221. HRCe, S.I.D. \& Others v Bulgaria of 21.07.2014.

222. ECtHR, Yordanova \& Others v Bulgaria of 24.04.2012.

223. ECtHR, Ivan Atanasov v Bulgaria of 02.12.2010.

224. ECtHR, Hadzhiyska v Bulgaria of 15.05.2012.

225. HRCe, Lubicon Lake Band v Canada of 26.03.1990.

226. British Columbia SCt, Canada, Halalt First Nation v British Columbia of 13.07.2011.

227. Boyd, David R. "No Taps, No Toilets: First Nations and the Constitutional Right to Water in Canada." McGill Law Journal 57 (2011): 81-134.

228. Ontario Court of Appeals, Pikangikum First Nation v Nault of 24.10.2012, 2012 ONCA 705; in $2013 \mathrm{SCt}$ dismissed the application for leave to appeal.

229. UNO. "UNO document $\mathrm{CERD} / \mathrm{C} / \mathrm{CAN} / \mathrm{CO} / 19-20$ of 09.03.2012." 2012. Available online: http://tbinternet.ohchr.org/_layouts/treatybodyexternal/Download.aspx?symbolno $=\mathrm{CERD} / \mathrm{C} / \mathrm{CA}$ N/CO/19-20\&Lang=En (accessed on 6 August 2015).

230. SCt Chile, Case 5339-2013 of 25.09.2013.

231. Constitutional Court, Colombia, Carolina Murcia Otálora v Empresas Públicas de Neiva of 06.08.2009.

232. Constitutional Court, Colombia, Flor Enid Jimenez de Correa v Medellin Public Companies of 17.04.2007.

233. SCt Costa Rica, Carlos Roberto Mejia Chacon v Municipalidad de Santa Ana of 30.07.1993, Case 3705-93.

234. De Albuquerque, Catarina. "Report A/HRC/12/24/Add.1 of the Mission to Costa Rica." 2009. Available online: http://www2.ohchr.org/english/bodies/hrcouncil/docs/15session/A.HRC.15.31. Add.1_en.pdf (accessed on 3 August 2015).

235. SCt Costa Rica, Comité Pro-No Construcción de la Urbanización Linda Vista v Minister of the Environment of 25.02.2004.

236. HRCe, Martinez Portorreal v Dominican Republic of 05.11.1987.

237. IACtHR, Kichwa Community of Sarayaku v Ecuador of 27.06.2012.

238. San Sebastian, Miguel, and Anna Karin Hurtig. "Oil exploitation in the Amazon basin of Ecuador: A public health emergency." Pan American Journal of Public Health 15 (2004): 205-11.

239. ECtHR, Mamère v France of 07.11.2006.

240. ECtHR, Caron \& Others v France of 29.06.2010.

241. ECtHR, Consorts Richet \& Le Ber v France of 18.11.2010.

242. ECtHR, Winterstein \& Others v France of 17.10.2013.

243. ECeSR, European Federation of National Organisations Working with the Homeless $v$ France of 05.12.2007.

244. Administrative Court of Appeal, Nancy, France, Préfet du Doubs v Commune d"Audincourt of 11.06.2009.

245. ECtHR, Greenpeace \& Others v Germany of 12.05.2009.

246. HRCe, Georgopoulou v Greece of 29.07.2010.

247. ECeSR, International Federation for Human Rights v Greece of 23.01.2013.

248. IACnHR, Lallion v Grenada of 21.10.2002.

249. HRC, Haraldsson \& Sveinsson v Iceland of 24.10.2007. 
250. SCt India, Bandhua Mukti Morcha v Union of India of 16.12.1983, 1984 AIR 802, 1984 SCR (2) 67.

251. SCt India, Water Supply \& Sewage v State of Haryana of 29.02.1996, 1996 SCC (2)572, JT 1996 (6) 107.

252. Kerala High Court, Perumatty Grama Panchayat v State of Kerala of 16.12.2003.

253. SCt India, State Of West Bengal v Kesoram Industries Ltd of 15.01.2004, civil appeal 1532/1993.

254. SCt India, State of Tamil Nadu $v$ State of Kerala of 07.05.2014, case 3/2006.

255. SCt India, Union Carbide Corporation v Union of India of 14.02.1989, JT 1989 (1)296, 1989 SCALE (1) 380.

256. SCt India, Charan Lal Sahu v Union of India of 22.12.1989, 1990 AIR 1480, 1989 SCR Suppl. (2) 597 .

257. SCt India, M.C. Mehta v Union of India of 20.12.1986, 1987 AIR 1086, 1987 SCR (1) 819.

258. SCt India, Vellore Citizens Welfare Forum v Union of India of 28.08.1996, 1996 AIR, (SC) 2715 (1996).

259. SCt India, Jagannath v Union of India of 11.12.1996, (1996) INSC 1592, (1997)2 SCC 87.

260. SCt India, Virendra Gaur v State of Haryana of 24.11.1994, 1994 Suppl. (6) SCR 78.

261. SCt India, Olga Tellis \& Others vs Bombay Municipal Corporation of 10.07.1985, 1986AIR180, 1985SCR Supl (2)51.

262. SCt India, Animal \& Environment Legal Defence Fund v Union of India of 05.03.1997, 1997(2) SCR 728.

263. SCt India, A.P. Pollution Control Board v Prof. Nayudu, I of 01.12.2000 and II of 22.12.2000.

264. Constitutional Court Indonesia, Judicial Review of Law No. 7/2004 on Water Resources, Judgment of 13.07.2005.

265. SCt Israel, Salim Abu Madigam v Israel Land Administration of 14.04.2007, HCJ 2887/04.

266. Murthy, Sharmila L., Mark Williams, and Elisha Baskin. "The Human Right to Water in Israel: A Case Study of the Unrecognized Bedouin Villages in the Negev." Israel Law Review 46 (2014): 25-59.

267. SCt Israel, Pardess Hanna Council v Minister of Agriculture of 08.12.1964, HCJ 221/64.

268. ECtHR, Guerra v Italy of 19.02.1998.

269. ECtHR, Giacomelliv Italy of 02.11.2006.

270. ECtHR, Di Sarno \& Others v Italy of 10.01.2012.

271. ECtHR, Sud Fondi srl \& others v Italy of 20.01.2009.

272. ECeSR, European Roma Rights Centre v Italy of 07.12.2005.

273. HRCe, Silbert Daley v Jamaica of 31.07.1998.

274. ACnHPR, Centre for Minority Rights Development v Kenya of 27.11.2009.

275. High Court, Embu, Kenya, Ibrahim Sangor Osman v Minister for Provincial Administration of 16.11.2011.

276. ECtHR, Vides Aizsardzības Klubs v Latvia of 27.05.2004.

277. ECtHR, Asselbourg \& Greenpeace v Luxembourg of 29.06.1999.

278. ECtJ, European Commission v Luxembourg of 28.11.2013, C-576/11.

279. Malaya High Court, Kuala Lumpur, Malaysia, Rajah Ramachandran v PBAPP of 02.03.2004.

280. Mexico SCt Justice, amparo en revisión 631/2012 of 08.05.2013. 
281. SCt Nepal, Leaders v Godawi Marble Industries of 31.10.1995.

282. SCt Nepal, Dil Bahadur Bishwakarma v Government of 02.05.2006, Writ Petition 3303.

283. Court of Appeal, Limburg, Netherlands, Case HD 200.018.358 of 02.03.2010.

284. SCt Pakistan, West Pakistan Salt Miners Labor Union at Khwra Khelum v Industries and Mineral Development at Punjab of 12.07.1994, Case 120/1993, 1994 SCMR.

285. IACtHR, Loor v Panama of 23.11.2010.

286. IACtHR, Yakye Axa Indigenous Community v Paraguay of 17.06.2005.

287. IACtHR, Sawhoyamaxa Indigenous Community v Paraguay of 29.03.2006.

288. IACtHR, Xákmok Kásek Indigenous Community v Paraguay of 26.08.2010.

289. HRCe, Poma Poma v Peru of 24.04.2009.

290. SCt Philippines, Juan Antonio Oposa \& Others v Department for Environment \& Natural Resources of 30.07.1993, case 101083.

291. ECtHR, Matos e Silva Lda \& Others v Portugal of 16.09.1996.

292. Constitutional Court of Portugal, A v Empresa Pública das Águas de Lisboa of 30.11.2004.

293. ECHR, Tătar v Romania of 27.01.2009.

294. ECtHR, Butan \& Dragomir v Romania of 14.02.2008.

295. ECtHR, Radu v Romania of 13.10.2009.

296. ECtHR, Stoicescu v Romania of 16.07.2009.

297. ECtHR, Ushakovv Russia of 25.10.2011.

298. ECtHR, Fedotov v Russia of 25.10.2005.

299. ECtHR, Fadeyeva v. Russia of 09.06.2005.

300. UNO Committee on the Elimination of Racial Discrimination, LR v Slovak Republic of 10.03.2005.

301. Constitutional Court of Slovenia, Case UP156/98 of 11.02.1999.

302. Constitutional Court of South Africa, Lindiwe Mazibuko v City of Johannesburg of 08.10.2009, CCT 39/09, 2009 ZACC 28.

303. Constitutional Court of South Africa, Joe Slovo Community v Thubelisha Homes of 10.06.2009.

304. HRCe, Michael \& Brian Hill v Spain of 02.04.1997.

305. ECtHR, López Ostra v Spain of 09.12.1994.

306. ECtHR, Mangouras v Spain of 08.01.2009.

307. Sunga, Lyal S. "Does climate change kill people in Darfur?" Journal of Human Rights and the Environment 2 (2011): 64-85.

308. ACnHPR, Sudan Human Rights Organization v Sudan of 27.05.2009.

309. IACtHR, Saramaka People v Suriname of 28.11.2007.

310. UNO. "UNO document CERD/C/SUR/CO/12 of 12.03.2009." 2009. Available online: http://tbinternet.ohchr.org/_layouts/treatybodyexternal/Download.aspx?symbolno $=$ CERD/C/SUR /CO/12 (accessed on 6 August 2015).

311. ECtHR, Zander v. Sweden of 25.11.1993.

312. Smets, Henri. "The Right to Water in National Legislations." 2006. Available online: http://www.worldwatercouncil.org/fileadmin/wwc/Programs/Right_to_Water/Pdf_doct/Smets_R TW_in_national_legislations.pdf(accessed on 31 July 2015).

313. ECtJ, European Commission v Sweden of 06.10.2009, C-438/07.

314. HRCe, Kurbanova v Tajikistan of 12.11.2003. 
315. UNO Committee against Torture, Imed Abdelli v Tunisia of 14.11.2003.

316. ECtHR, Ylldirır v Turkey of 02.12.2010.

317. ECtHR, Turgut \& Others v Turkey of 08.07.2008.

318. ECtHR, Taşkin v. Turkey of 10.11.2004.

319. ECtHR, Lemke v Turkey of 06.06.2007.

320. ECtHR, Okyay \& Others v Turkey of 12.07.2005.

321. Tintner, Johannes, Manfred Kühleitner, Erwin Binner, Norbert Brunner, and Ena Smidt. "Modeling the final phase of landfill gas generation from long-term observations." Biodegradation 23 (2011): 407-17.

322. ECtHR, Öneryıldız v Turkey of 30.11.2004.

323. ECtHR, Melnik v Ukraine of 28.03.2005.

324. ECtHR, Dubetska v Ukraine of 10.02.2011.

325. Gearty, Conor. "Do human rights help or hinder environmental protection?” Journal of Human Rights and the Environment 1 (2010): 7-22.

326. ECtHR, Steel \& Morris v United Kingdom of 15.02.2005.

327. High Court Division of SCt United Kingdom, $R v$ Director General of Water Services ex parte Oldham MBC of 30.01.1998.

328. IACnHR, M\&C Dann v USA of 27.12.2002.

329. US Court of Appeals for the Ninth Circuit, South Fork Band v USA Dept. Int. of 03.12.2009, 588 F3d 718(2009).

330. District Court, Columbus, OH, USA, Kennedy v City of Zanesville of 10.07.2008.

331. Administrative Court Branch of the Supreme Tribunal of Justice, Condominio del Conjunto Residencial Parque Choroni v Hidrocentro of 22.06.2005.

332. HRCe, Peter Mwamba v Zambia of 10.03.2010.

333. HRCe, Kalenga v Zambia of 27.07.1993.

334. Bluemel, Erik B. "The Implications of Formulating a Human Right to Water." Ecology Law Quarterly 31 (2005): 957-1006.

335. Dubreuil, Céline. “The Right to Water: From Concept to Implementation.” 2006. Available online: http://www.worldwatercouncil.org/fileadmin/wwc/Library/RightToWater_FinalText_Cover.pdf (accessed on 31 July 2015).

336. Starkl, Markus, Norbert Brunner, Yuxiu Zhong, Pe Li, Yining Wang, and Mats Ericson. "Overcoming barriers for the management of scarce water resources in Northern China." Water Policy 16 (2014): 991-1008.

337. Adinkrah, Mensah. "Witchcraft Accusations and Female Homicide Victimization in Contemporary Ghana." Violence against Women 10 (2004): 325-56.

338. UNO. "UNO document E/C.12/ISR/CO/3 of 02.12.2011." 2011. Available online: http://tbinternet.ohchr.org/_layouts/treatybodyexternal/Download.aspx?symbolno=E/C.12/ISR/C O/3\&Lang=En (accessed on 6 August 2015).

339. Kamphuis, Charis. "Foreign mining, law and the privatization of property: A case study from Peru." Journal of Human Rights and the Environment 3 (2012): 217-53. 
340. United Nations High Commissioner for Human Rights. "Views of the United States of America on Human Rights and Access to Water." 2007. Available online: www2.ohchr.org/english/ issues/water/contributions/UnitedStatesofAmerica.pdf (accessed on 31 July 2015).

341. Thor, Emily M. "The Human Right to Water in the United States: Why So Dangerous?" Global Business \& Development Law Journal 1 (2013): 315-41.

(C) 2015 by the authors; licensee MDPI, Basel, Switzerland. This article is an open access article distributed under the terms and conditions of the Creative Commons Attribution license (http://creativecommons.org/licenses/by/4.0/). 